\title{
Cyclical co-movements of private real estate, public real estate and equity markets: a cross-continental spectrum
}

Article

Accepted Version

Creative Commons: Attribution-Noncommercial-No Derivative Works 4.0

Devaney, S. and Xiao, Q. (2017) Cyclical co-movements of private real estate, public real estate and equity markets: a cross-continental spectrum. Journal of Multinational Financial Management, 42-43. pp. 132-151. ISSN 1042444X doi: https://doi.org/10.1016/j.mulfin.2017.10.002 Available at https://centaur.reading.ac.uk/75389/

It is advisable to refer to the publisher's version if you intend to cite from the work. See Guidance on citing.

Published version at: http://dx.doi.org/10.1016/j.mulfin.2017.10.002

To link to this article DOI: http://dx.doi.org/10.1016/j.mulfin.2017.10.002

Publisher: Elsevier

All outputs in CentAUR are protected by Intellectual Property Rights law, including copyright law. Copyright and IPR is retained by the creators or other copyright holders. Terms and conditions for use of this material are defined in the End User Agreement.

www.reading.ac.uk/centaur 
Central Archive at the University of Reading

Reading's research outputs online 


\title{
Cyclical co-movements of private real estate, public real estate and equity markets: A cross-continental spectrum
}

\section{Dr Steven Devaney}

Henley Business School, University of Reading, RG6 6UD, UK

E: s.devaney@reading.ac.uk T: +44 (0) 1183784035

\section{Dr Qin Xiao*}

Hull University Business School, University of Hull, Hull, HU6 7RX, UK

E: q.xiao@hull.ac.uk T: +44(0) 1482463172

* Corresponding author

\begin{abstract}
Whether returns from investing in real estate shares reflect equity market or real estate market trends is an important question for investors seeking liquid, low cost exposure to real estate. We consider the relationship between real estate shares, private real estate investments and equity markets for five locations: Australia, Hong Kong, Singapore, UK and US. We utilise spectral and cross-spectral techniques to decompose each time series into cyclical components of differing frequencies. This allows correlations for a range of cyclical components to be analysed. Our results suggest that returns from real estate shares share a number of short frequency cycles with the equity market. Longer cycles are evident in both real estate shares and private real estate returns, but these cycles are not always shared. Hence, real estate shares and private real estate may not always be close substitutes, even over longer horizons, but the relationship varies across our locations.
\end{abstract}

\section{Keywords}

Real estate; spectral analysis; transaction indices; disaggregated data.

JEL code: G12, G15, C32, C58, R30, R39

\section{Author bio}

Dr Steven Devaney is an Associate Professor at the Henley Business School and his research interests are focused on pricing, appraisal and liquidity in commercial real estate investment markets.

Qin Xiao is a Senior Lecturer in Finance in Hull University Business School. Her research interests include speculative bubbles in housing markets and the impact of real estate market crash on the financial system. More recently, she focuses on the impact of financialization on real estate and commodity markets. Qin is interested in mathematical modelling as well as computational econometrics. 


\section{Introduction and motivation}

Global assets under management (AUM) were valued at c. \$69tn in 2016 and the importance of alternative asset classes in contributing to that total has grown (BCG, 2017). The prominence of commercial real estate as a major alternative asset class within institutional investment portfolios has also risen in recent years. Preqin (2016) report that the average allocation to commercial real estate increased from $6.7 \%$ of AUM in 2011 to $8.5 \%$ in 2015, while the average target allocation rose from $9.1 \%$ to $9.8 \%$ over the same period. There are two distinctive ways of investing in commercial real estate. ${ }^{1}$ One involves direct ownership of real properties such as office towers or shopping malls while the other is to invest in firms or funds that own real properties, which can be either publicly listed on stock exchanges or unlisted. The market for real properties is often referred to in the literature as the private real estate market and that for the publicly listed real estate firms or funds as the public real estate market.

For institutional investors, the relationship between the performance of publicly listed real estate firms and the underlying private markets in which they invest is a topic with important implications for investment strategies. Direct ownership of private real estate requires significant capital with management responsibilities and little liquidity. To avoid these problems, many investors instead make investments in either listed real estate shares or unlisted real estate funds (Baum and Hartzell, 2012). If the performances of the two types of real estates are similar, they can be regarded as substitutes in a portfolio context, leaving investors to allocate capital between these choices based on preferences for liquidity or control, as well as amount of capital available. If they are dissimilar, then the nature of any differences in performance or risk needs to be understood.

Empirical research has generated mixed findings as to whether private and public real estate provide similar investment returns through time. Reasons include variations in the periods studied and methods used. Recent studies reviewed in section 2 have used cointegration techniques to try and address this question. These assume that a time series contains only two components, a short-run and a long-run component, with a consensus emerging that a long-run relationship does exist even if

\footnotetext{
${ }^{1}$ This study does not cover the housing market which concerns mostly individual rather than institutional investors, and which is extensively studied in a different strand of literature.
} 
the performance of private and public real estate diverges in the short run. However, such techniques do not address the issue of 'how short is the short-run and how long is the long-run'. Other research suggests that there are different lengths of cycles in real estate performance, driven by cycles in credit, economic activity and urban development (Wheaton, 1999, Barras, 2009). Whether such cycles are shared between private and listed real estate has rarely been examined and cannot be addressed using a cointegration-based approach.

As such, we will employ spectral analysis to establish whether multiple regular cycles are embedded within the seemingly irregular fluctuations that are present in real estate returns data. Results can then be compared for different series to see whether similar cyclical patterns are evident in each case. We also use cross-spectral analysis to test the relatedness of a pair of time series at individual cycles. This includes, but is not limited to, short-run and long-run cycles with the duration/period of such cycles explicitly estimated. Our results indicate the importance of longer run cycles in both the public and private real estate markets, but shorter cycles are also important in the former case, while the relatedness of the pair over longer horizons varies by geographical location, indicating that private and public real estate investments are not always substitutable even in the long run. This contrasts with the consensus emerging from other studies.

Furthermore, most studies that have explored such issues have focused on the US and UK commercial real estate markets, and with aggregate data. We compare the performance of public real estate to that of private real estate for Australia, Hong Kong, Singapore on top of the UK and the US. All these are places where mature and highly developed markets for investable real estate exists. This mix allows markets of different scales in different regions and with different institutional arrangements to be examined and contrasted. Since cycles in the real estate sector for office buildings can vary from those for shopping malls or industrial parks, data aggregated across these different sectors may blur, or even distort, the analytical results of the researchers. We will thus explore how results vary with respect to different types of commercial property using sector-level data.

Finally, many earlier studies relied on appraisal based rather than transaction based indices to measure private real estate returns. However, appraisal based indices are thought to understate the 
volatility of real estate and to not capture market turning points in a timely manner. ${ }^{2}$ This has led to the development of transaction based indices for commercial real estate in some countries. For the UK and the US, we can make direct comparison of whether the type of index matters for understanding how private and public real estate markets are linked. For other locations, we use either appraisal or transaction based series according to data availability. Using transaction indices does lead to some differences in our results.

We review relevant literature in the next section before discussing the methods in more detail. The data that we use is then explained prior to presenting the results of our spectral and crossspectral analyses. A final section concludes.

\section{Previous studies}

Investment in private commercial real estate typically entails a large capital cost, while high transaction costs and lengthy transaction times inhibit frequent trading. In contrast, shares in listed property companies and Real Estate Investment Trusts (REITs) can be bought in small quantities, are easier and cheaper to trade, and offer exposure to diversified portfolios of assets. Thus, they are an attractive alternative method of investing in real estate. Yet the performance of listed real estate companies can deviate from that of the real estate markets in which they have invested and their returns tend to be more volatile. Some reasons for this are as follows:

- Differences in the efficiency with which the public and private markets process price signals and other price relevant information (Geltner et al., 2003).

- Differences in the types of investor involved with each form of real estate, which may lead to different behaviours and responses (Barkham and Ward, 1999).

- Issues around the legal structure and management of listed real estate firms and the scope of their activities (whether they solely engage in real estate investment).

\footnotetext{
${ }^{2}$ For a summary of the issues concerning appraisal based indices, see GELTNER, D., MACGREGOR, B. \& SCHWANN, G. 2003. Appraisal Smoothing and Price Discovery in Real Estate Markets. Urban Studies, 40, 1047-1064. and EDELSTEIN, R. \& QUAN, D. 2006. How Does Appraisal Smoothing Bias Real Estate Returns Measurement? . Journal of Real Estate Finance and Economics, 32, 41-60.
} 
- Use of leverage by listed companies, whereas private real estate indices are typically constructed on an unlevered based.

- The appraisal basis of many commercial real estate indices, which contrasts with the use of price data to construct equity market indices.

Early empirical research noted the higher volatility of public real estate returns when compared to those from private real estate and a low contemporaneous correlation between them. Examples are Giliberto (1990), Gyourko and Keim (1992), Myer and Webb (1993), Fisher et al. (1994), Barkham and Geltner (1995) and Eichholtz and Hartzell (1996). In contrast, high correlations were found between return rates for public real estate and those for broader equity markets. Such patterns suggested that investors in public real estate companies did not receive the same diversification benefits as investors in private real estate. Yet this literature also found that movements in public real estate returns led those in the private market and had some predictive power. This was even the case where desmoothing methods were applied to adjust for potential smoothing and lagging in appraisal based series. ${ }^{3}$

Most of these early studies focused on the US and on the short run behaviour of returns. ${ }^{4}$ However, a lead-lag relationship could imply that longer term links exist between these forms of real estate investment, so subsequent studies explored long run behaviour using cointegration methods. Wang et al. (1997) demonstrated cointegration between public and private real estate returns for the UK, with the former found to Granger Cause the latter. Morawski et al. (2008) found cointegration for public and private real estate in both the UK and the US. Similar findings for four countries (Australia, Netherlands, UK and US) were reported by Yunus et al. (2012). However, results for the US in Glascock et al. (2000) and Tuluca et al. (2000) suggest that the relationships are complex, with feedback possible from the private real estate market to the REIT sector. A complex and interlinked

\footnotetext{
${ }^{3}$ Desmoothing involves the use of statistical methods to reduce or remove autocorrelation in appraisal based indices. See Geltner et al. (2003).

${ }^{4}$ They also covered periods that predated or overlapped a time of significant change and maturation in the US REIT sector. See Clayton and MacKinnon (2003).
} 
relationship for US asset classes was also suggested in work by (Nneji et al., 2013) on speculative bubbles. In all these cases, appraisal based series were used for private real estate returns.

Transaction based indices for real estate investment markets are less common, but several series exist for US commercial real estate. Oikarinen et al. (2011) used appraisal and transaction based indices to examine both short and long run dynamics between US private and public real estate. In each case, they found cointegration with an index for Equity REITs and that it was private real estate returns, not REIT returns, which adjusted to restore the relationship. In contrast, they did not find cointegration between any of these series and the US stock market. This suggests that public and private real estate offer similar diversification benefits over a long horizon. The appraisal based series lagged the REIT index by more than the transaction based index, but the authors noted that "since REIT returns lead also the transaction-based returns, the perceived lead-lag relation cannot only be attributed to appraisal smoothing effects" (p96).

Morawski et al. (2008) used an early US transaction index to check their correlation analysis of public and private real estate markets. They found that the lag from public to private real estate returns was reduced when a transaction index for private real estate was used, but it was not eliminated. Boudry et al. (2012) and Hoesli and Oikarinen (2012) used sector level transaction based indices to explore whether links between US private and public real estate were stronger at a more disaggregate level. The results of these studies affirm that REITs and the private market are linked in the long run, but disagree on whether adjustment to that relationship occurs in the returns of just one or both forms of real estate. However, Hoesli and Oikarinen used a wider range of tests and catered for leverage and economic influences when finding that predictability ran solely from the public to the private market.

Finally, Chan et al. (2011) explored relationships between US private real estate, Treasury bonds, equities, oil and gold. Using Markov switching models, they distinguished two regimes: an expansionary regime with positive returns for real estate and equities, and a crisis regime where returns were negative for these assets and stronger for Treasury bonds and gold. The correlation between equities and real estate increased during the crisis regime (see also Nneji et al. (2013)). Rather than use commercial real estate data, they utilised the Case-Shiller home price index, which 
is transaction based and published at a relatively high frequency. However, this does not correspond to the type of real estate that is commonly held in institutional investor portfolios and their study did not examine the performance of listed real estate companies either.

Studies for the US that use transaction based indices support the notion that, while linked in the long run, important differences exist between the performance of private and public real estate markets. Yet there is limited research on this outside a US context and it has relied primarily on cointegration to test the relationships. While cointegration is more sophisticated than analysing correlations or estimating standard linear regression models, all of these methods are time domain techniques that are typically applied within a linear framework. As such, they work well where asset returns are governed by linear dynamic systems, but they cannot detect non-linear dependencies and they also tend to assume a Gaussian distribution in return rates. These features are problematic when trying to identify the presence of different cycles in seemingly irregular real estate returns data.

Therefore, this study compares the cyclical properties of capital return rates using spectral and cross-spectral analysis, which are frequency domain techniques. Application of such techniques to private real estate prices or returns is rare. The closest comparator to our study is that of Brown and Liow (2001) who used spectral and cross-spectral analysis to compare aggregated private and public real estate prices in Singapore. They found evidence of an eight-year cycle in both private and public real estate markets, a high degree of coherence for this cycle and an insignificant lag on the part of the private real estate market.

Also related are the studies of Oppenheimer and Grissom (1998) and Wilson and Okunev (1999) who used these techniques to compare public real estate with the wider equity market. Both studies found that the returns for public real estate and stocks were significantly correlated at a common cycle, but the duration of this cycle varied between countries. Meanwhile, Liow (2007) compared public real estate returns across different countries to see if cycles were shared, thus reducing the potential for diversification. He compared public real estate in the UK, Japan, Singapore, Hong Kong and Malaysia, finding that the strongest links between cycles existed across the latter three markets. 


\section{Methods: Spectral and cross spectral analyses}

Spectral analysis involves decomposing a series into the sum of a number of cosine and sine components, a pair of which of the same frequency corresponds to a cycle of a particular duration. The amount of variance that is explained by a particular cycle can be plotted in the form of a spectral density diagram, analogous to a histogram, in which the peaks disclose the cycle lengths that are most important in the data to hand.

Consider a stationary random process of the form

$$
X_{t}=\sum_{j=1}^{k} a_{j} e^{i \omega_{j} t}
$$

where $\omega_{j}, j=1, \ldots, k$, is a set of real numbers with $\left|\omega_{\mathrm{j}}\right| \leq \pi$ and $a_{j}, j=1, \ldots, k$, a set of independent, complex random variables with

$$
\begin{aligned}
& E\left[a_{j}\right]=\mathbf{0}, \forall j \\
& E\left[a_{j} \overline{a_{j}}\right]=\sigma_{j}^{2}, \forall j \\
& E\left[a_{j} \overline{a_{k}}\right]=0, \forall j \neq k \\
& \text { where } \overline{a_{j}} \text { is the conjugate of } a_{j} . \text { For each } \mathrm{j} \\
& \boldsymbol{a}_{j} e^{i \omega_{j} t}=\boldsymbol{a}_{j}\left(\cos \omega_{j} t+\boldsymbol{i} \sin \omega_{j} t\right)
\end{aligned}
$$

which is a periodic function with frequency $\omega_{j} / 2 \pi$ cycles per unit of time, and period $2 \pi / \omega_{j}$ units of time per cycle. The element $\omega_{\mathrm{j}}$ is called the angular frequency measured in radians per time unit. The autocovariance of $\mathrm{X}_{\mathrm{t}}$ has a spectral representation of the form

$$
\mu_{\tau}=\int_{-\pi}^{\pi} e^{i t \omega} d F(\omega)
$$

where $\mathrm{F}()$ is the power spectral distribution function. When $F()$ is absolutely continuous, the above expression can be written as

$$
\mu_{\tau}=\int_{-\pi}^{\pi} e^{i t \omega} f(\omega) d \omega
$$

with $f()$ the power spectrum of the random process $\mathrm{X}_{\mathrm{t}}$. For a real, stationary process with $0 \leq$ $\omega_{\mathrm{j}} \leq \pi$,

$$
\mu_{\tau}=2 \int_{0}^{\pi} \cos \tau \omega f(\omega) d \omega
$$

All spectral estimates are of the form 


$$
\hat{f}\left(\omega_{j}\right)=\frac{1}{2 \pi}\left(\mu_{0}+\sum_{k=1}^{m} \mu_{k} \cos k \omega_{j}\right)
$$

where $\omega_{j}=\frac{\pi j}{m}, j=0, \ldots, m$, with $\mathrm{m}$ the cut-off point or number of lags used. The covariance estimate $C_{k}$ is similar to

$$
C_{k}=\frac{1}{n-k}\left(\sum_{t=1}^{n-k} x_{t} x_{t+k}-\frac{1}{n-k} \sum_{t=1+k}^{n} x_{t} \sum_{t=1}^{n-k} x_{t+k}\right)
$$

A weight $\lambda_{\mathrm{k}}$ is assigned to covariance of different lags. Different weights and smoothing formula are used in different spectral estimating approaches (for example, Tukey-Hanning and Parzen).

The $(100-\alpha) \%$ confidence interval of $\hat{f}\left(\omega_{j}\right), \forall j$ is given by

$$
\left[T_{\alpha}(m, n) \hat{f}\left(\omega_{j}\right), T_{\alpha}^{\prime}(m, n) \hat{f}\left(\omega_{j}\right)\right]
$$

Or

$$
\left[\log T_{\alpha}(m, n)+\log \hat{f}\left(\omega_{j}\right), \log T_{\alpha}{ }^{\prime}(m, n)+\log \hat{f}\left(\omega_{j}\right)\right]
$$

For Tukey -Hanning and Parzen estimates,

$$
T_{\alpha}(m, n)=\frac{\chi_{100-\alpha}^{2}(k)}{k}, \text { and } T_{\alpha}{ }^{\prime}(m, n)=\frac{\chi_{\alpha}^{2}(k)}{k}
$$

where $\mathrm{n}$ is the number of observations in the sample, $\mathrm{m}$ the number of lags used and $\mathrm{k}$ is the equivalent degree of freedom ('equivalent' because the data may not be exactly normally distributed) with $k=2 n / m$.

For two different series, it is possible that only some of the cycles occurring in one also occur in the other. For instance, there may be short run fluctuations in the liquid public real estate market that are not replicated in the illiquid private real estate market. Such movements could distort correlations averaged over a given sample period (commonly used in the literature) even though long term cycles are shared by both series. In this case, cross-spectral analysis can be used to identify the correspondence between series at individual cycle level, as well as any lead-lag relationships that may be present (see (Granger, 1969) and (Iacobucci, 2005).

Consider a pair of real bivariate stationary processes $X_{t}$ and $Y_{t}$ with absolutely continuous spectral density functions. Their autocovariances are respectively $\mu_{\mathrm{xx}}(\tau)$ and $\mu_{\mathrm{yy}}(\tau)$ and crosscovariance $\mu_{\mathrm{xy}}(\tau)$ with spectral representations as follows 


$$
\begin{aligned}
& \mu_{x x}(\tau)=2 \int_{0}^{\pi} \cos \tau \omega f_{x}(\omega) d \omega \\
& \mu_{y y}(\tau)=2 \int_{0}^{\pi} \cos \tau \omega f_{y}(\omega) d \omega \\
& \mu_{x y}(\tau)=2 \int_{0}^{\pi} \cos \tau \omega c(\omega) d \omega-2 \int_{0}^{\pi} \sin \tau \omega q(\omega) d \omega \\
& =\int_{-\pi}^{\pi} e^{i \tau \omega} C_{r}(\omega) d \omega
\end{aligned}
$$

where $f_{x}(\omega)$ and $f_{y}(\omega)$ are the power spectra of the processes $X_{t}$ and $Y_{t}$ respectively; $c(\omega)$ is the co-spectrum, $q(\omega)$ the quadrature spectrum, and

$$
C_{r}(\omega)=c(\omega)+i q(\omega)
$$

is known as the power cross-spectrum between $\mathrm{X}_{\mathrm{t}}$ and $\mathrm{Y}_{\mathrm{t}}$. These functions obey the coherence-inequality:

$$
c^{2}(\omega)+q^{2}(\omega) \leq f_{x}(\omega) f_{y}(\omega)
$$

Inverting the covariance function above gives

$$
\begin{aligned}
& f_{x}(\omega)=\frac{1}{2 \pi}\left(\mu_{x x}(0)+2 \sum_{\tau=1}^{\infty} \mu_{x x}(\tau) \cos \tau \omega\right) \\
& f_{y}(\omega)=\frac{1}{2 \pi}\left(\mu_{y y}(0)+2 \sum_{\tau=1}^{\infty} \mu_{y y}(\tau) \cos \tau \omega\right) \\
& c(\omega)=\frac{1}{2 \pi}\left(\mu_{x y}(0)+2 \sum_{\tau=1}^{\infty}\left(\mu_{y x}(\tau)+\mu_{y x}(\tau)\right) \cos \tau \omega\right) \\
& q(\omega)=\frac{1}{\pi}\left(\sum_{\tau=1}^{\infty}\left(\mu_{y x}(\tau)-\mu_{y x}(\tau)\right) \sin \tau \omega\right)
\end{aligned}
$$

A measure of the correlation between the frequency components of the two processes is given by

$C(\omega)=\frac{c^{2}(\omega)+q^{2}(\omega)}{f_{x}(\omega) f_{y}(\omega)}, \quad 0 \leq C(\omega) \leq 1$

which is called the coherence between $X_{t}$ and $Y_{t}$ and $\omega$.

$C(\omega)$ is a scaled measure of covariance that is bounded by 0 and 1 and which is analogous to the square of the correlation coefficient between two samples. A plot of $C(\omega)$ against angular frequency $\omega$ over $0 \leq \omega \leq \pi$ produces a coherence diagram. The critical value of $C(\omega)$ is given by $\sqrt{\left(1-\exp \left(\frac{\ln (\alpha)}{n / m-1}\right)\right)}$, where $\alpha$ is the predetermined significance level, $n$ the number of observations and $m$ the number of frequency bands estimated (see (Granger, 1964) page 79). 
The same frequency component shared by two processes may be out of phase; for example, the $\omega_{\mathrm{j}}$ frequency component of the public real estate index may lead the same component of the private real estate index by 2 quarters. A measure of the phase difference is

$$
\varphi(\omega)=\tan ^{-1}\left(\frac{q(\omega)}{c(\omega)}\right)
$$

And the plot of $\varphi(\omega)$ against $\omega$ over $0 \leq \omega \leq \pi$ is called the phase diagram. Both $\mathrm{C}(\omega)$ and $\phi(\omega)$ can be estimated using sample data. Together, they capture the strength of any correspondence between the series being compared and the extent to which a shared cycle in one series leads or lags the emergence of that cycle in the other series. The confidence bands for phase angle can be found in Granger and Hatanaka (1964), p.80.

\section{Data}

Quarterly data were obtained on the performance of private real estate, public real estate and equity markets up to Q4 2013 or Q1 2014 for Australia, Hong Kong, Singapore, the UK and the US (Table 1). In all cases, capital return rates expressed in local currency terms were used because total return series were not consistently available. For equity markets, the indices used were the Australia All Ordinaries Price Index, the Hong Kong Hang Seng Price Index, the Singapore Straits Times Index, the UK FTSE All Share Index and the S\&P 500 for the USA. For all countries except the US, the DataStream indices for the listed real estate sector were chosen on the basis that these offered the longest time series. Listed real estate series for the US were obtained from the National Association of Real Estate Investment Trusts (NAREIT), including indices for REITs that invest in different types of real estate.

Table 1 Descriptive statistics for capital return series. Data are collected from various sources as described in the main text. $T_{-}=$transaction based index; $V_{-}=$appraisal based index; $E_{-}=$real estate equities; $E Q=$ general equities;_All = all property;_A = apartments;_I = industrial;_O = office;_R = retail.

\begin{tabular}{|c|c|c|c|c|c|}
\hline & Period & Count & Mean & S.D. & Auto-correlation \\
\hline Australia & & & & & \\
\hline V_All & $1984 Q 4-2013 Q 4$ & 116 & 0.63 & 2.09 & 0.94 \\
V_I & $1984 Q 4-2013 Q 4$ & 116 & 0.41 & 1.90 & 0.90 \\
V_O & $1984 Q 4-2013 Q 4$ & 116 & 0.41 & 2.55 & 0.94 \\
V_R & $1984 Q 4-2013 Q 4$ & 116 & 1.08 & 1.28 & 0.91 \\
E_All & $1973 Q 1-2014 Q 1$ & 164 & 1.96 & 11.56 & 0.08 \\
\hline
\end{tabular}




\begin{tabular}{|c|c|c|c|c|c|}
\hline EQ & 1971Q1-2014Q1 & 172 & 2.09 & 9.59 & 0.02 \\
\hline \multicolumn{6}{|c|}{ Hong Kong } \\
\hline T_I & 1978Q4 - 2014Q1 & 141 & 2.37 & 6.37 & 0.61 \\
\hline T_O & 1986Q1 - 2014Q1 & 112 & 2.74 & 8.33 & 0.57 \\
\hline$T_{-} R$ & $1978 Q 4-2014 Q 1$ & 141 & 2.74 & 6.72 & 0.51 \\
\hline E_All & 1973Q1 - 2014Q1 & 164 & 4.19 & 22.72 & -0.06 \\
\hline EQ & 1973Q1 - 2014Q1 & 198 & 4.19 & 17.01 & 0.00 \\
\hline \multicolumn{6}{|c|}{ Singapore } \\
\hline T_I & 1975Q1 - 2014Q1 & 156 & 1.69 & 7.02 & 0.63 \\
\hline T_O & 1975Q1-2014Q1 & 157 & 1.75 & 8.93 & 0.69 \\
\hline$T \_R$ & $1975 Q 1-2013 Q 4$ & 156 & 1.04 & 7.32 & 0.07 \\
\hline E_All & 1973Q1 - 2014Q1 & 165 & 2.99 & 21.04 & 0.05 \\
\hline EQ & 1973Q1 - 2014Q1 & 165 & 2.60 & 14.12 & 0.04 \\
\hline \multicolumn{6}{|c|}{ The United Kingdom } \\
\hline T_All & $1981 Q 4-2013 Q 4$ & 128 & 0.69 & 4.37 & 0.23 \\
\hline T_I & $1981 Q 4-2013 Q 4$ & 128 & 0.57 & 5.57 & -0.12 \\
\hline T_O & $1981 Q 4-2013 Q 4$ & 128 & 0.53 & 5.49 & 0.00 \\
\hline T_R & $1981 Q 4-2013 Q 4$ & 128 & 1.01 & 4.45 & 0.22 \\
\hline V_All & $1977 Q 2-2013 Q 4$ & 146 & 0.87 & 2.97 & 0.80 \\
\hline V_l & 1977Q2 - 2013Q4 & 146 & 0.79 & 3.16 & 0.82 \\
\hline $\mathrm{V} \_\mathrm{O}$ & $1977 Q 2-2013 Q 4$ & 146 & 0.65 & 3.18 & 0.80 \\
\hline$V_{-} R$ & $1977 Q 2-2013 Q 4$ & 146 & 1.29 & 3.29 & 0.71 \\
\hline E_All & 1965Q1 - 2014Q1 & 196 & 2.63 & 13.46 & 0.02 \\
\hline $\mathrm{EQ}$ & 1965Q1 - 2014Q1 & 207 & 2.28 & 10.20 & 0.06 \\
\hline \multicolumn{6}{|c|}{ The United States } \\
\hline T_All & 1984Q1 - 2014Q1 & 120 & 0.87 & 6.13 & -0.16 \\
\hline T_A & 1994Q1 - 2011Q1 & 68 & 1.48 & 5.75 & -0.15 \\
\hline T_I & 1994Q1 - 2011Q1 & 68 & 1.20 & 5.79 & -0.13 \\
\hline T_O & 1994Q1 - 2011Q1 & 68 & 1.34 & 5.50 & -0.11 \\
\hline$T_{-} R$ & 1994Q1 - 2011Q1 & 68 & 1.10 & 5.82 & -0.12 \\
\hline V_All & $1977 Q 4-2014 Q 1$ & 145 & 0.41 & 2.13 & 0.77 \\
\hline V_A & $1977 Q 4-2014 Q 1$ & 145 & 0.82 & 2.20 & 0.75 \\
\hline V_l & $1977 Q 4-2014 Q 1$ & 145 & 0.35 & 2.12 & 0.79 \\
\hline $\mathrm{V} \_\mathrm{O}$ & $1977 Q 4-2014 Q 1$ & 145 & 0.27 & 2.82 & 0.67 \\
\hline$V \_R$ & $1977 Q 4-2014 Q 1$ & 145 & 0.53 & 1.91 & 0.63 \\
\hline E_All & $1971 Q 4-2014 Q 1$ & 169 & 1.42 & 8.85 & 0.13 \\
\hline E_A & $1993 Q 4-2014 Q 1$ & 81 & 1.86 & 10.12 & 0.12 \\
\hline E_I & $1993 Q 4-2014 Q 1$ & 81 & 1.80 & 12.84 & 0.25 \\
\hline E_O & $1993 Q 4-2014 Q 1$ & 81 & 2.01 & 11.19 & 0.21 \\
\hline$E_{-} R$ & $1993 Q 4-2014 Q 1$ & 81 & 2.03 & 11.47 & 0.14 \\
\hline $\mathrm{EQ}$ & $1971 Q 4-2014 Q 1$ & 201 & 1.94 & 8.08 & 0.09 \\
\hline
\end{tabular}

Page | 12

In the UK and US, private real estate series were available on a transaction and an appraisal basis, but we could only obtain appraisal based indices for Australia. The appraisal based indices for the US are published by the National Council of Real Estate Investment Fiduciaries (NCREIF) while 
MSCI produces such indices for Australia and the UK. ${ }^{5}$ The MSCI and NCREIF indices are constructed using data from properties owned by major institutional investors. They are value weighted series and exclude the effects of any leverage or trading activity. ${ }^{6}$ For the UK, the appraisal series used here is based on a monthly index that allowed quarterly return rates to be computed back to 1987. A comparable quarterly index produced by Jones Lang LaSalle then allowed extension back to Q2 1977.

The transaction based indices for US private real estate were produced by the MIT Centre for Real Estate in collaboration with NCREIF. The construction of these indices is discussed in detail by Fisher et al. (2007). They are derived from regressions of a sample of sale prices on to preceding appraisals and time dummy variables. A similar method was applied to the MSCI data by Devaney and Martinez Diaz (2011) to create transaction based price series for the UK. For Hong Kong, transaction based series track commercial real estate prices at sector level. These are compiled by the Rating and Valuation Department of Hong Kong. For Singapore, sector level transaction price series are produced and released by the Urban Redevelopment Authority.

The different series are summarised by Table 1, which shows the period for which each series was available, the number of observations and some basic descriptive statistics: mean, standard deviation and first order autocorrelation. Real estate equities exhibit higher average capital return rates than private real estate and the average return rate is sometimes higher than that of the wider equity market. They also have the most volatile capital returns in all countries, outstripping private real estate and the equity market. Meanwhile, the appraisal based return rates for private real estate are less volatile than the corresponding transaction based rates and they exhibit high levels of first order autocorrelation, which accords with the literature on appraisal smoothing (see Geltner et al. (2003)).

Finally, contemporaneous correlations between public real estate return rates and equity market return rates were 0.78 in the case of Australia, 0.94 for Hong Kong, 0.91 for Singapore, 0.79

\footnotetext{
${ }^{5}$ The MSCI series are a continuation of indices that were formerly produced by Investment Property Databank ${ }^{6}$ See MSCI (2016) and NCREIF (2015) for more details.
} 
for the UK and 0.62 for the US. In comparison, the correlations between public and private real estate returns were between 0.1 and 0.2 for Australia, Hong Kong and the US, between 0.2 and 0.3 for Singapore and around 0.3 for the UK; the basis of the private real estate index makes little difference to this. The stronger contemporaneous correspondence between public real estate and the wider equity market is consistent with earlier research, but this measure is too crude to capture how strongly series might be related at different cycle lengths.

\section{Results}

Most long economic time series, after removing the trend component, exhibit a series of long irregular fluctuations. These irregularities may arise as the aggregate expression of some regular cycles. The most important of these cycles for real estate markets are likely to be the urban development cycle ( $16-20$ years), the property development cycle ( $8-10$ years) and the business cycle (4-5 years) (Barras, 2009). There could also be higher frequency cycles such as Mack's subcycle ( 2 years) and an annual component, which is also called a seasonal variation.

The method we employ requires a sample of at least seven times the period of a cycle to be estimated to confirm its existence (see Granger and Hatanaka (1964) page 17). That means, in most of the cases in our sample, the longest cycle we can confirm is the business cycle (Table 2 Panel A). We nevertheless report (but not confirm) longer cycles, in Table 2 Panel B, when the estimated spectral densities are very high at their corresponding frequency bands which are also often accompanied by their repeated harmonics supporting their existence (c.f. Granger and Hatanaka (1964) page 63). Identified cycles which have period shorter than $1 / 7^{\text {th }}$ of the samples are recorded in Table 2 Panel C. Within each country, when a cyclical component is shared and significantly correlated across markets or sectors, the corresponding significance level of their coherence and the lead/lag relationship (measured by a phase difference) are noted in the same table for ease of reference. In that event, the coherence and phase are also plotted pairwise in a diagram and displayed in Figure 3.

Table 2 Cyclical components by periods (in quarters)

\begin{tabular}{|c|l|l|l|}
\hline $\begin{array}{c}\text { Output } \\
\text { Type }\end{array}$ & Index & Sector & Cyclical components \\
\hline
\end{tabular}




\begin{tabular}{|c|c|c|c|c|c|c|c|c|c|c|c|c|c|}
\hline & & & A & \multicolumn{2}{|c|}{ B } & \multicolumn{8}{|c|}{ C } \\
\hline \multicolumn{14}{|c|}{ Australia } \\
\hline \multirow[t]{6}{*}{ Cycle } & $\mathrm{V}$ & All & 16.57 & 38.00 & . & . & . & . & . & . & . & . & . \\
\hline & & 1 & 16.57 & 38.00 & . & . & . & . & . & . & . & . & . \\
\hline & & 0 & 16.57 & 38.00 & . & . & . & . & . & . & . & . & . \\
\hline & & $\mathrm{R}$ & 16.57 & 38.00 & . & . & . & . & . & . & . & . & . \\
\hline & $E$ & & 23.43 & . & . & 25.33 & . & . & 2.81 & . & . & . & . \\
\hline & $E Q$ & & 24.57 & . & . & 25.33 & . & . & 2.81 & 2.45 & 2.38 & $<=2.00$ & . \\
\hline \multicolumn{14}{|c|}{ Hong Kong } \\
\hline \multirow[t]{5}{*}{ Cycle } & \multirow[t]{3}{*}{$T$} & 1 & 20.14 & . & . & . & .10 .57 & 6.17 & 3.89 & 3.22 & 2.24 & . & . \\
\hline & & 0 & 16.00 & . & . & . & 12.33 & 6.73 & . & . & 2.11 & . & . \\
\hline & & $\mathrm{R}$ & 20.14 & . & . & . & 12.33 & 6.73 & . & 3.22 & . & . & . \\
\hline & $E$ & & 23.43 & . & . & 23.50 & 13.43 & 7.23 & 3.48 & 2.85 & . & . & . \\
\hline & EQ & & 23.43 & . & . & 23.50 & 13.43 & 7.23 & 3.48 & 2.85 & 2.47 & 2.09 & . \\
\hline \multirow[t]{3}{*}{ C\&PH } & \multirow[t]{2}{*}{$\mathrm{T}$} & I_O & . & $* * * 0.14$ & . & . & . & . & . & . & . & . & . \\
\hline & & $O_{-} R$ & . & . & . & . & $\begin{array}{c}*_{-} \\
0.68 \\
\end{array}$ & ${ }^{* *} 0.26$ & . & . & . & . & . \\
\hline & $E_{-} E Q$ & & . & . & . & $* * 0.06$ & $\begin{array}{l}* *_{-} \\
0.65\end{array}$ & $* * 1.73$ & $\begin{array}{l}* * *- \\
0.06\end{array}$ & $* * * 0.48$ & . & . & \\
\hline \multicolumn{14}{|c|}{ Singapore } \\
\hline \multirow[t]{5}{*}{ Cycle } & \multirow[t]{3}{*}{$\mathrm{T}$} & 1 & 22.29 & 34.00 & & . & 7.85 & 5.37 & 3.29 & . & . & . & . \\
\hline & & 0 & 22.29 & 34.00 & 25.50 & . & . & 5.37 & 3.92 & 3.40 & 2.22 & $<=2.00$ & . \\
\hline & & $\mathrm{R}$ & 22.29 & 34.00 & 25.50 & & 11.33 & . & . & 3.64 & 2.37 & 2.32 & . \\
\hline & $E$ & & 23.57 & 34.00 & 25.50 & . & 11.33 & 6.00 & . & 3.52 & 2.62 & . & . \\
\hline & EQ & & 23.57 & & 25.50 & . & 11.33 & 6.00 & . & 3.52 & . & . & . \\
\hline \multirow[t]{4}{*}{$C \& P H$} & \multirow[t]{3}{*}{$T$} & 1 & . & $* * 0.81$ & . & . & . & $* * 2.57$ & . & . & . & . & . \\
\hline & & $I-R$ & . & $* *-0.59$ & . & . & . & . & . & . & . & . & . \\
\hline & & $O_{-} R$ & . & $\begin{array}{l}* * *_{-} \\
1.62 \\
\end{array}$ & $\begin{array}{l}* * *- \\
2.09 \\
\end{array}$ & . & . & . & . & . & . & . & . \\
\hline & $E_{-} E Q$ & & . &. & . & . & $\begin{array}{l}* * *_{-} \\
0.22\end{array}$ & $* 0.05$ & . & $* * * 0.62$ & . & . & . \\
\hline \multicolumn{14}{|c|}{ The United Kingdom } \\
\hline \multirow[t]{10}{*}{ Cycle } & \multirow[t]{4}{*}{$T$} & All & 18.29 & 28.00 & 21.00 & . & . & . & . & . & 2.90 & . & \\
\hline & & 1 & 18.29 & 28.00 & 21.00 & . & . & 8.40 & 5.25 & 3.82 & 2.90 & 2.33 & \\
\hline & & 0 & 18.29 & 28.00 & 21.00 & . & . & & 5.25 & 3.65 & 2.71 & & \\
\hline & & $\mathrm{R}$ & 18.29 & 28.00 & 21.00 & . & . & 7.64 & 5.25 & & & 2.47 & \\
\hline & \multirow[t]{4}{*}{$\mathrm{V}$} & All & 20.86 & 28.00 & 21.00 & . & . & & 5.25 & 3.65 & & & \\
\hline & & 1 & 20.86 & 28.00 & 21.00 & . & . & & 5.25 & 3.65 & & & . \\
\hline & & 0 & 20.86 & 28.00 & 21.00 & . & . & & 5.25 & 3.65 & & & . \\
\hline & & $R$ & 20.86 & 28.00 & 21.00 & . & . & & 5.25 & 3.65 & & & . \\
\hline & $E$ & & 28.00 & 28.00 & & . & . & 8.40 & 5.25 & 3.65 & 2.71 & 2.40 & . \\
\hline & $E Q$ & & 28.00 & 28.00 & & . & . & 8.40 & 5.25 & 3.65 & . & . & . \\
\hline$C \& P H$ & T_E & R_E & . & $*^{* *}-0.37$ & & . & . & . & . & . & . & . & . \\
\hline & $V_{-} E$ & R_E & . & **0.02 & & . & . & . & . & . & . & . & . \\
\hline & $T$ & I_O & . & $* *-2.91$ & $*^{* *}-0.41$ & . & . & . & . & . & . & . & . \\
\hline & & I_R & . & $*-0.81$ & $* *-1.69$ & . & . & . & . & . & . & . & . \\
\hline & & O_R & . & & $*-1.00$ & . & . & . & . & . & . & . & . \\
\hline & $\mathrm{V}$ & I_O & . & $* *-2.54$ & $\begin{array}{l}* * *- \\
0.31 \\
\end{array}$ & . & . & . & $*-0.13$ & . & . & . & . \\
\hline & & I_R & . & & $*-2.44$ & . & . & . & & ${ }^{\circ}$ & . & . & . \\
\hline & & O_R & . & & $*-2.03$ & . & . & . & $* * 0.08$ & $* * 1.76$ & . & . & . \\
\hline & T_V & All & . & $* * * 0.09$ & $\begin{array}{l}* * *- \\
0.07 \\
\end{array}$ & . & . & . & . & . & . & . & . \\
\hline & & 1 & . & $\begin{array}{l}* * * \\
0.11 \\
\end{array}$ & $\begin{array}{l}* * * \\
0.20 \\
\end{array}$ & . & . & . & . & . & . & . & . \\
\hline & & 0 & . & $* * * 0.18$ & $* * * 0.09$ & . & . & . & . & . & . & . & . \\
\hline
\end{tabular}

Page | 15 


\begin{tabular}{|c|c|c|c|c|c|c|c|c|c|c|c|c|c|}
\hline & & $\mathrm{R}$ & . & ${ }^{* * *} 0.27$ & $\begin{array}{l}* * *- \\
0.09\end{array}$ & . & & . & . & & . & . & \\
\hline \multicolumn{14}{|c|}{ The United States } \\
\hline \multirow[t]{16}{*}{ Cycle } & \multirow[t]{5}{*}{$T$} & All & 17.14 & 25.33 & & . & . & . & . & 4.00 & 3.17 & 2.38 & \\
\hline & & A & 9.71 & . & 22.00 & . & . & . & . & 0 & . & 2.32 & \\
\hline & & $\mathrm{I}$ & 9.71 & . & 22.00 & . & . & . & . & 4.89 & . & 2.32 & \\
\hline & & 0 & 9.71 & . & 22.00 & . & . & . & . & & . & 2.32 & \\
\hline & & $\mathrm{R}$ & 9.71 & . & 22.00 & . & . & . & . & 4.89 & . & . & \\
\hline & \multirow[t]{5}{*}{$\mathrm{V}$} & All & 20.71 & 32.00 & & . & . & . & . & . & 3.84 & . & . \\
\hline & & A & 20.71 & . & 22.00 & . & . & . & . & . & . & . & \\
\hline & & 1 & 20.71 & . & 22.00 & . & . & . & . & . & . & . & . \\
\hline & & $\mathrm{O}$ & 20.71 & . & 22.00 & . & . & . & . & . & . & . & \\
\hline & & $R$ & 20.71 & . & 22.00 & . & . & . & . & . & . & . & . \\
\hline & \multirow[t]{5}{*}{$E$} & All & 24.14 & 28.00 & . & 22.40 & 8.62 & 8.00 & 5.89 & 4.87 & . & 2.60 & 2.07 \\
\hline & & A & 11.57 & . & 22.00 & . & . & . & . & 4.89 & . & 2.59 & \\
\hline & & 1 & 11.57 & . & 22.00 & . & . & . & . & & . & . & \\
\hline & & 0 & 11.57 & . & 22.00 & 14.67 & . & . & . & & . & . & \\
\hline & & $\mathrm{R}$ & 11.57 & . & 22.00 & 14.67 & . & . & . & 4.89 & . & . & . \\
\hline & EQ & & 24.14 & 28.00 & & & 8.62 & 8.00 & 5.33 & 5.09 & 3.61 & 2.60 & $<2.00$ \\
\hline \multirow[t]{22}{*}{ C\&PH } & \multirow[t]{3}{*}{ T_E } & $A$ & . & . & $* * 0.35$ &. & . &. & . & . & . &. & . \\
\hline & & I & . & . & $* * 1.70$ & . & . & . & . & & . & . & \\
\hline & & 0 &. &. & $* 3.60$ & . & . & . & . & . & . & . & . \\
\hline & $V_{-} E$ & 1 & . & . & $* * 2.64$ & . & . & . & . & 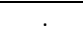 & . & . & . \\
\hline & \multirow[t]{5}{*}{$\mathrm{E}$} & A_I & . & . & $*-0.37$ & . & . & . & . & & . & . & \\
\hline & & A_O & . & . & ${ }^{* *} 0.29$ & . & . & . & . & . & . & . & . \\
\hline & & A_R &. & . & & . & . &. &. & ${ }^{* * *} 0.12$ &. &. & . \\
\hline & & I_O &. &. & $* 0.87$ & . & . &. & . & . & . & . & . \\
\hline & & I_R & . & . & $* * 0.88$ & . & . & . & . & & . & . & \\
\hline & \multirow[t]{6}{*}{$T$} & A_I &. &. & $\begin{array}{l}* * *- \\
0.36\end{array}$ &. & . &. &. & . &. &. & \\
\hline & & A_O & . & . & $* *-1.03$ & . & . & . & . & . & . & . & . \\
\hline & & A_R & . & . & $* * 0.64$ & . & . & . & . & & . & . & \\
\hline & & I_O & . & . & $\begin{array}{l}* * * \\
0.65\end{array}$ & . &. & . & . & & . & . & \\
\hline & & R_I & . & . & $* *-0.92$ & . & . & . & . & -0.59 & . & . & \\
\hline & & R_O & . & . & $*-1.63$ & . & . & . & . & . & . & . & . \\
\hline & \multirow[t]{3}{*}{ V } & A_I &. &. & $\begin{array}{l}* * * \\
0.01\end{array}$ & . &. & 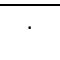 & . & . & . & . & . \\
\hline & & A_O & . & . & $* *-0.01$ &. & . &. & . & . & . & . & . \\
\hline & & I_O & . & . & ${ }^{* * *} 0.00$ & . & . & . & . & . & . & . & . \\
\hline & \multirow[t]{4}{*}{ T_V } & A & . & . & $* *-0.42$ & . & . & . & . & . & . & . & . \\
\hline & & $\mathrm{I}$ & . & . & $\begin{array}{l}* * * \\
0.98\end{array}$ & . & . & . & . & & . & . & \\
\hline & & 0 & . & . & $\begin{array}{l}* *{ }_{-} \\
0.68\end{array}$ & . & . & . & . & & . & . & \\
\hline & & $R$ & . & . & $*_{-0.96}$ & . & . & . & . & & . & . & \\
\hline
\end{tabular}

Note: (i) Panel A lists the benchmark cycles which have durations equal to $1 / 7^{\text {th }}$ of their corresponding sample; panel B lists cycles strongly suggested by the spectral density plots but have durations longer than their corresponding benchmark cycles; panel C lists cycles with durations shorter than those of the corresponding benchmark cycles. All numbers are in quarters (ii) The section titled "Cycle" displays the cyclical components of a series while the section titled "C\&PH" (coherence and phase) displays the lead-lag relation between a pair of significantly correlated component. A positive number for the pair $X \_Y$ means $X$ leads $Y$, otherwise $X$ lags behind $Y$, e.g. Hong Kong public real estate leads the equity market by 0.06 quarters at the 23.5-quarter cycle but lags behind by 0.7 quarters at the 13.4-quarter cycle. (iii) *,**,***indicates shared components are significantly correlated at 10\%, 5\% and $1 \%$ respectively. (iv) The critical value for coherence is given 
by $\sqrt{\left(1-\exp \left(\frac{\ln (\boldsymbol{\alpha})}{n / m-1}\right)\right)}$, where $\alpha=$ significance level, $n=$ sample size. We have chosen $m=$ the nearest integer of $n / 3$ in our estimation. (v) The calculation of phase difference is based on Granger and Hatanaka (1964), $p$. 97-8. (vi) $V$ = appraisal based index; $T$ = transaction based index; $E=$ public real estate; $E Q=$ equity market; $A$ =apartment; $I=$ industrial; $O=$ office; $R=$ retail.

To maximise the number of observations for detecting cyclical components, spectral analysis was performed on the entire time series available in each case. Meanwhile, cross-spectral analysis for the identification of a pairwise significant coherence at a shared component was conducted over the full period for which both were available. Spectral density plots for the private real estate series are shown in Figure 1 and for the public real estate and equity series in Figure 2. From these figures, it is clear that low-frequency (long) cycles are typically the most influential in private real estate and make a major contribution to the total variance of the respective series. Within the private real estate market, it is usually the office sector where cycles in prices appear to be most visible. In contrast, for public real estate markets, shorter cycles appear to be just as influential as long term cycles. It is also obvious from these plots that, within a country, cycles in public real estate returns exhibit similar frequencies to those shown by the wider equity market and not to those of private real estate. In what follows, we will discuss these and other features in detail.

Figure 1 Spectral density plots - private real estate. A peak indicates either a cycle or the harmonic of a cycle with the duration measured in quarters along the horizontal axis.

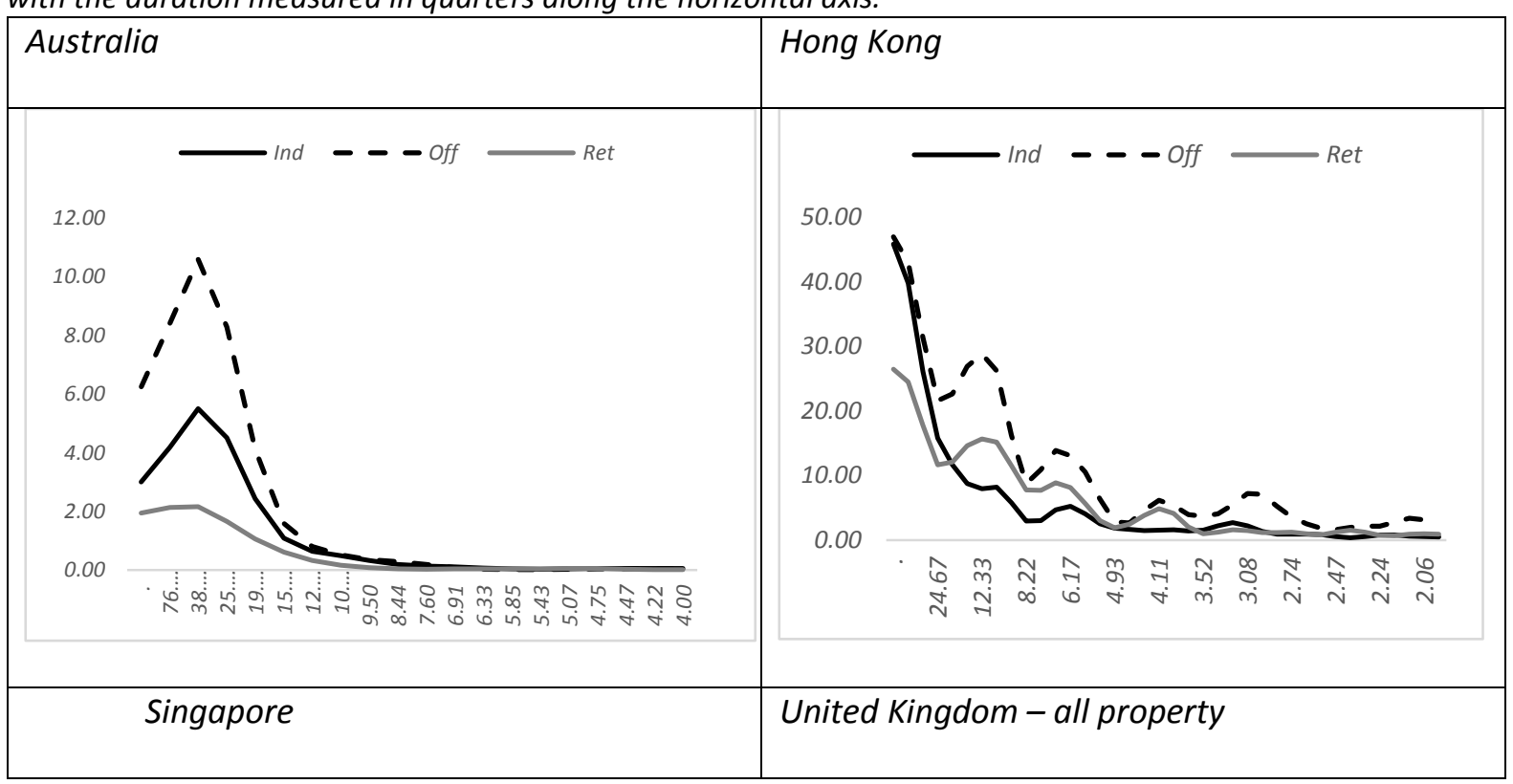




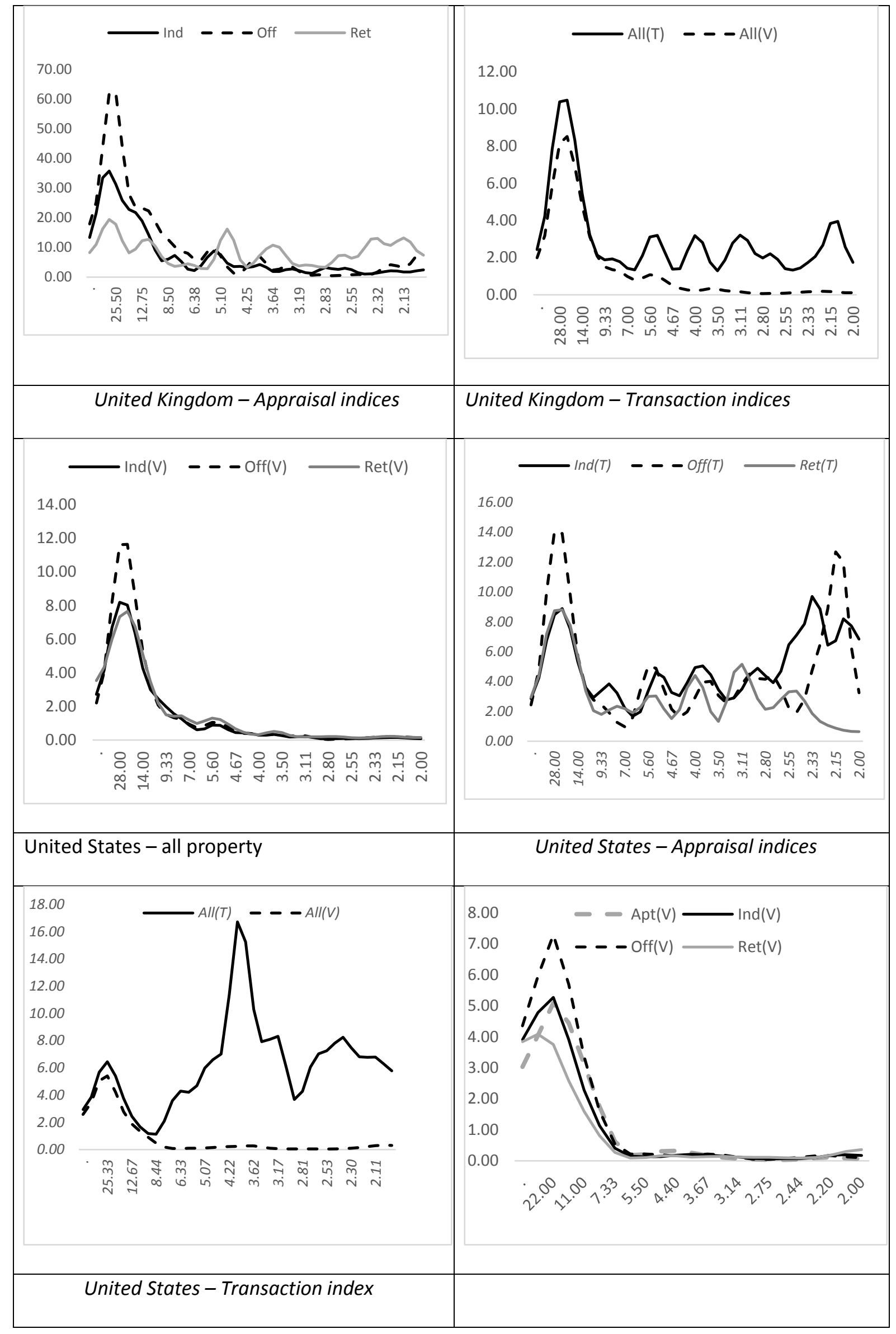

Page | 18 


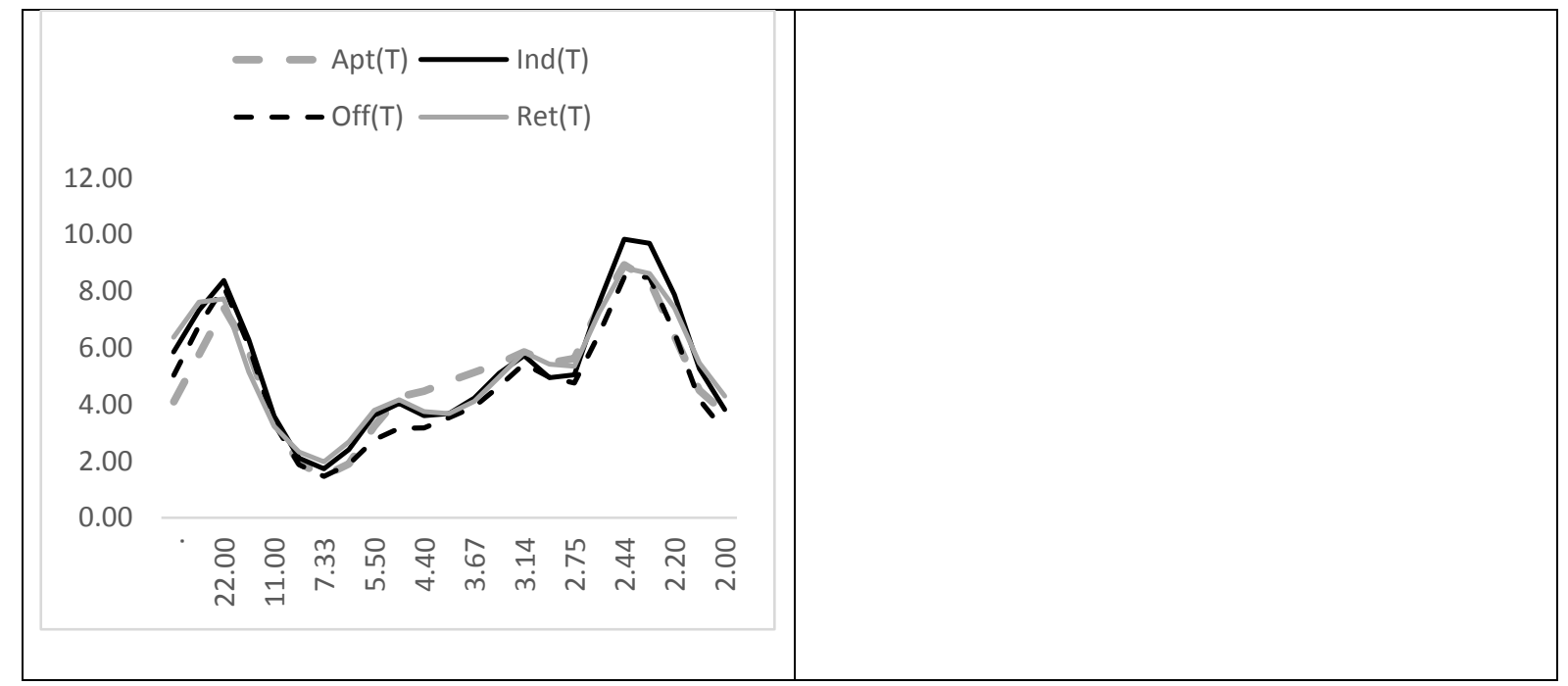

Page | 19

Figure 2 Spectral density plots - public real estate and equity.

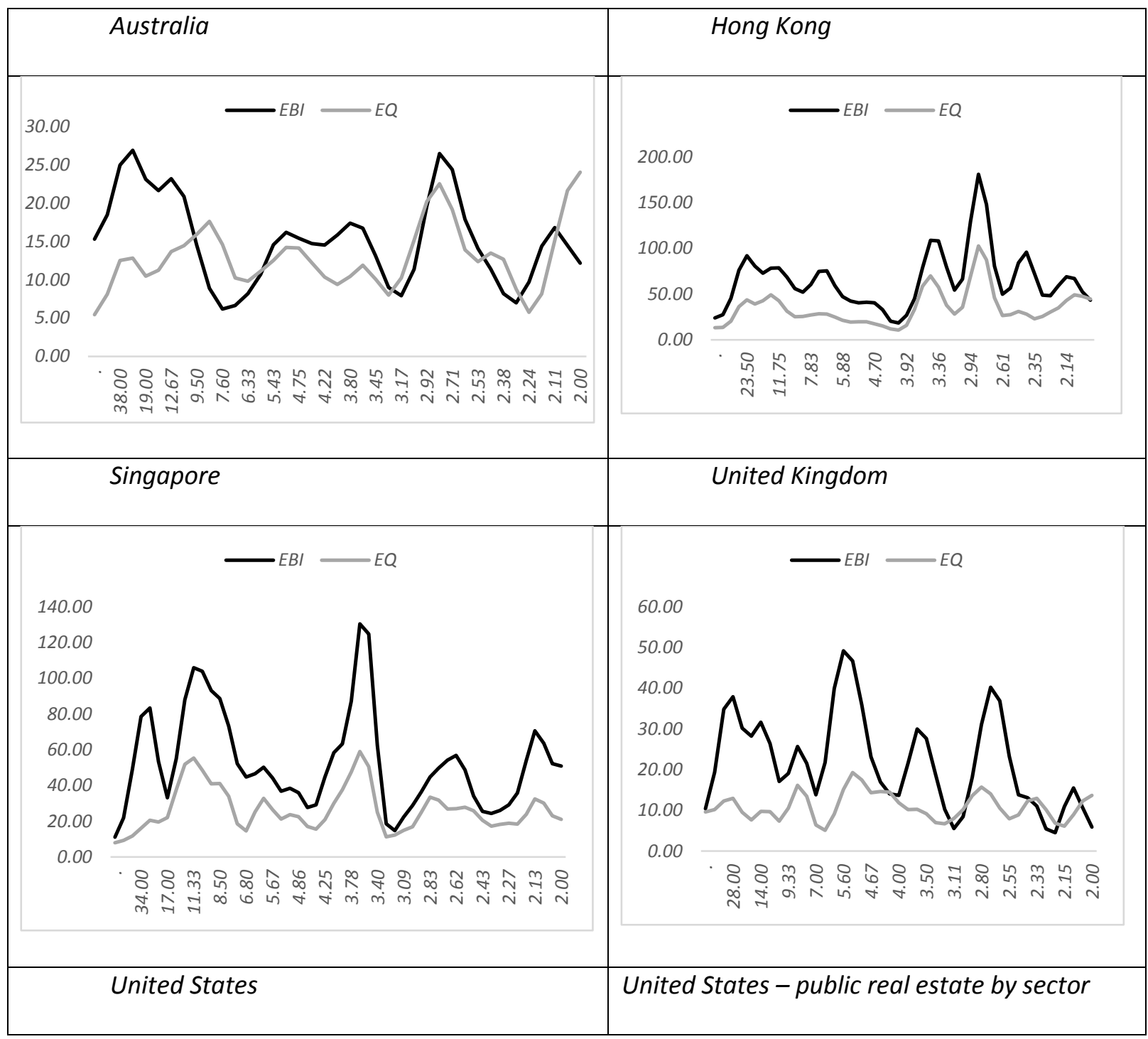




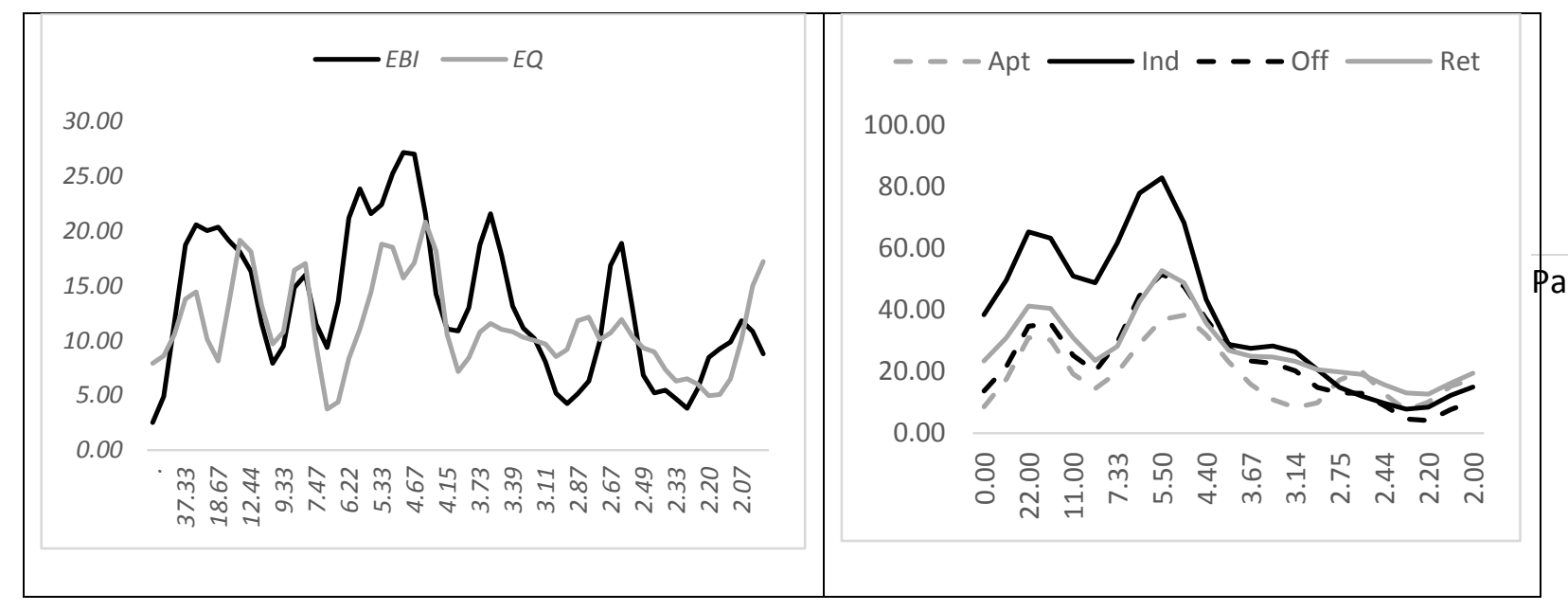

Figure 3 Coherence and phase angle - private RE, public RE and equity Only significantly correlated markets/sectors are plotted. (i) coherences are measured by the left axis and phase angles in rad by the right axis. (ii)The horizontal axis indicates the period (in quarters) of each cyclical component. (iii) $(T)=$ transaction based index; $(V)$ = appraisal based index; $(E)=$ public real estate.

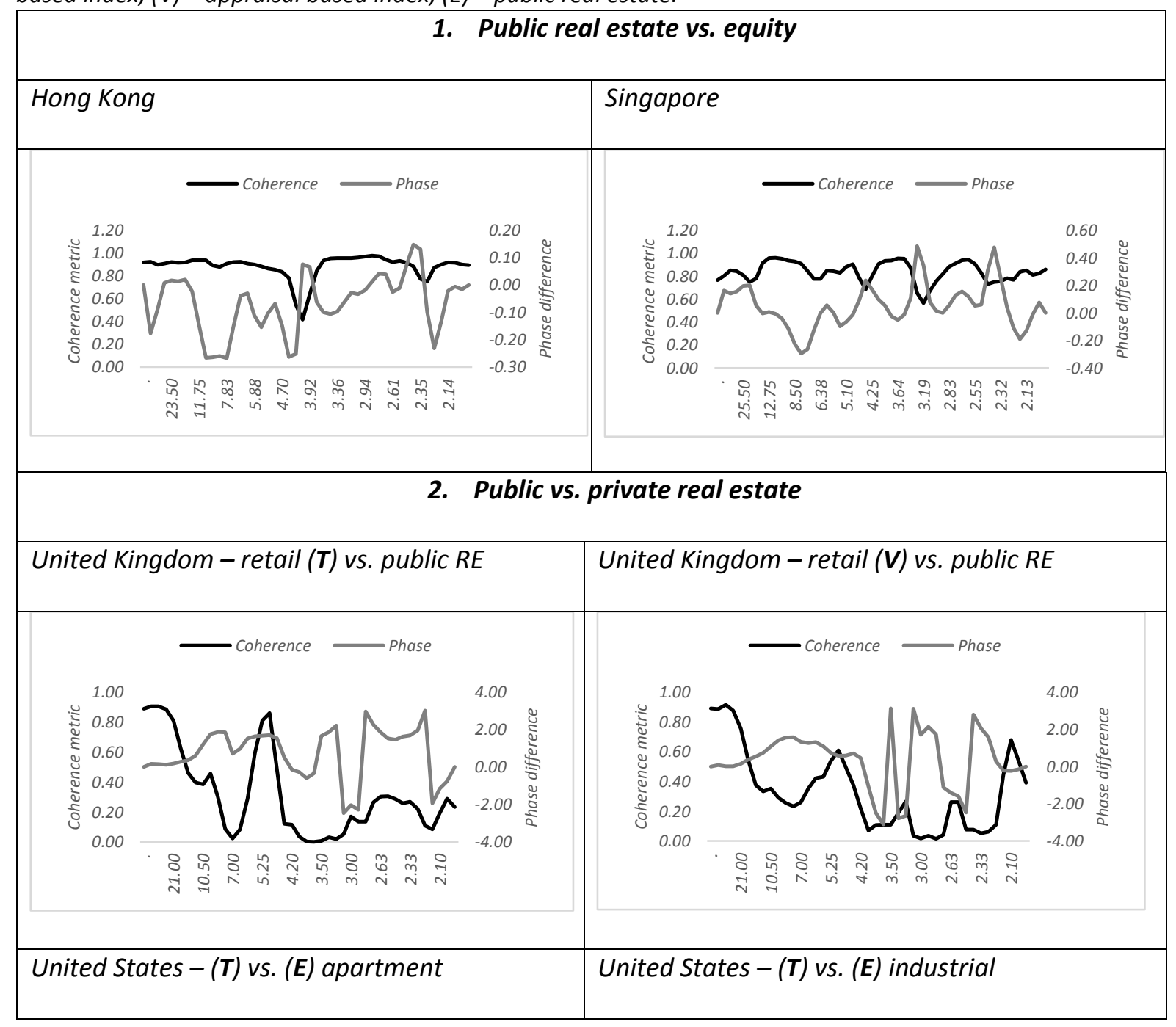




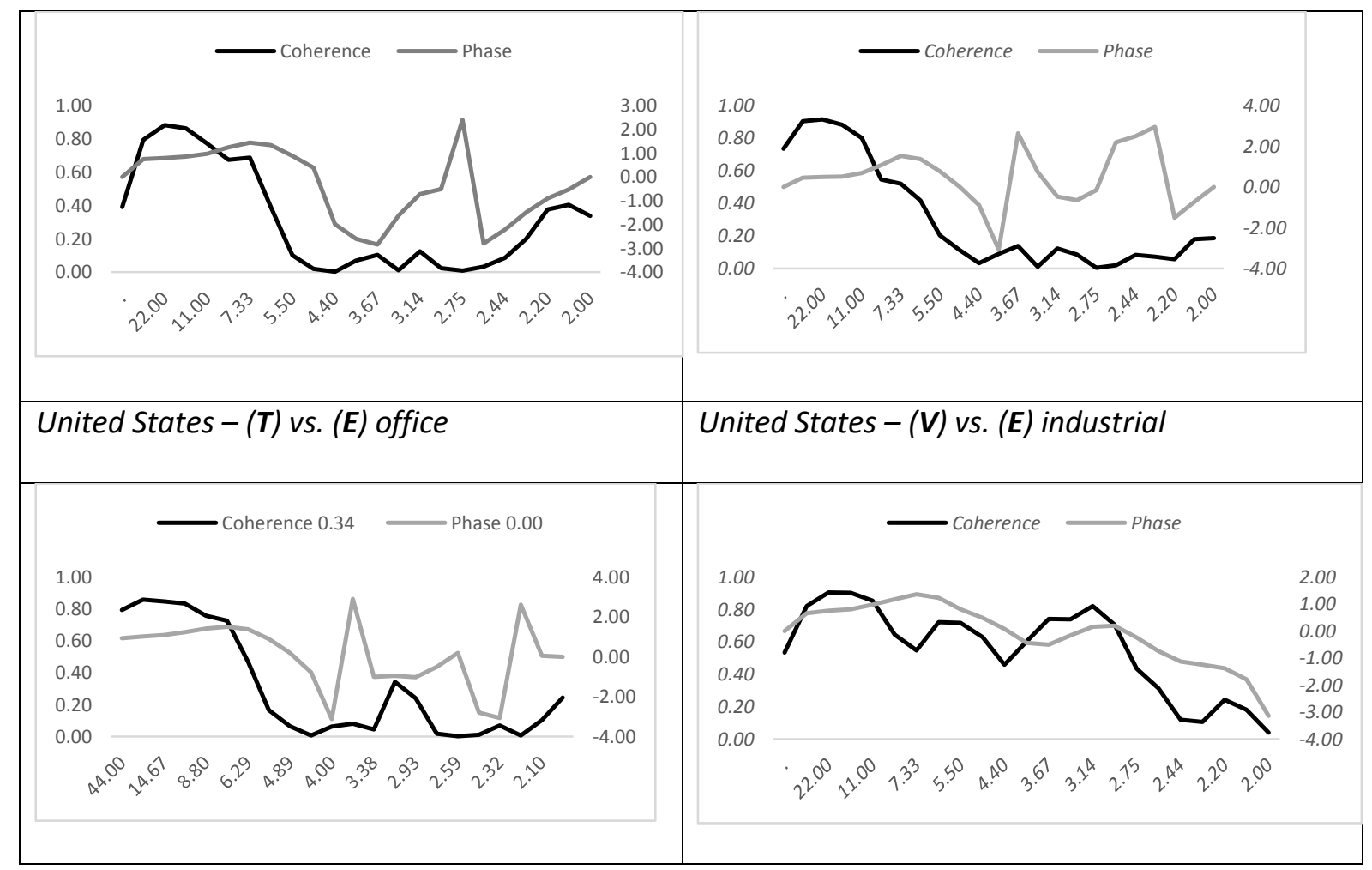

\subsection{Public real estate vs. equity}

In Australia, public real estate and the equity market share a 2.8-quarter cycle and a 6.3 -year cycle ${ }^{7}$, yet they are not significantly correlated across the two markets even at the level. In UK, the public real estate and equity markets share a 7-year, a 2.1-year, a 1.3-year and a 3.7-quarter cycle. The two markets are not significantly correlated at any of these cycles, though. In the US, the spectral density plots spell a shared 7-year cycle between the public real estate and the equity market with the caveat that it is longer than $1 / 7^{\text {th }}$ of the sample. The two markets also share a 2.2-year, a 2-year and a 2.6quarter cycle which are well within the range allowed by the sample length. Like in the UK, these two markets are not significantly correlated at any of these four components.

In contrast, in Hong Kong, the public real estate market shares five cyclical components with the equity market: a 5.9-year, a 3.4-year, a 1.8-year, a 3.48-quarter and a 2.9-quarter cycle, with the last one the most dominant in both. These two markets are significantly correlated at the $1 \%$ level at the three low frequency cycles and at 5\% at the two high frequency cycles. The public real estate

\footnotetext{
${ }^{7}$ Technically speaking, our sample is slightly shorter than required to confirm this 6.3 -year cycle. To confidently estimate a cycle of this length, we need 177 quarters' observations when in fact we have 164 quarters' and 172 quarters' observation for the public RE and the equity market respectively (see Table $1 \& 2$ ).
} 
market moves in near tandem with the equity market at the 5.9-year and the 3.48-quarter cycle, lags it by 0.7 quarters at the 3.4 -year cycle, but leads it by 1.73 quarters and 0.48 quarters at the 1.8 -year and 2.9-quarter cycle respectively.

Similarly, the public real estate market in Singapore appears to share three cycles of different durations with the equity market: 2.8-year, 1.5-year, and 3.5-quarter. The two series are significantly correlated at all three components at $1 \%, 10 \%$ and $1 \%$ respectively (see Table 2). Public real estate lags the wider equity market by 0.22 quarters at the 2.8 -year cycle, but leads it at the 3.5 -quarter cycle while moving in near tandem with the latter at the 1.5 -year cycle. This suggests that the nature of the relationship is complex and cannot be easily characterised as one market always leading or lagging the other.

\subsection{Public vs. private real estate}

In Australia, no common component could be detected between the private and public real estate markets. In Hong Kong, like in Australia, the public and private real estate market share no cyclical components. In Singapore, although the density plots suggest tentatively that the public real estate market shares an 8.5-year cycle with all three sectors of the private market, the coherence is below the critical values at the conventional significance levels. The plots also suggest that the public real estate shares a 6.3-year cycle with the office and retail sectors (which is also shared by the equity market), but their coherences again are below the critical values. This contrasts with Brown and Liow (2001), who suggested a shared 8 year cycle between public real estate and the aggregated private real estate market, as well as significant co-movement between them, with the former leading in the short-run.

In UK, we found that public real estate is significantly correlated with the retail sector at a 7-year cycle at 5\% level. This is true whether the latter is measured using a transaction or an appraisal index. When transaction data is used, the estimates indicate that the retail sector leads the public real estate market by 0.37 quarters and, when an appraisal index is used, the two markets appear to have hardly any phase difference at this shared cycle. The significant coherence at this shared cycle is not revealed using the aggregate 'all property' series for the private market. It also 
contrasts with the conventional wisdom as to how public and private real estate markets are linked, showing the importance of examining these links at different cycle frequencies.

In the US, when aggregate 'all property' data are used for private real estate, again, no shared components are identified between the public and private markets. Using sector-level data and transaction based indices, the estimated coherence suggests that these two markets are significantly correlated at the 5\% significance level at a 5.5-year cycle in the apartment and industrial sectors, and at the $10 \%$ level in the office sector. In contrast, using appraisal based indices, we only found significant coherence at this shared component in the industrial sector. Using transaction based indices also helps us to pick up higher frequency cycles that are missing in the appraisal series (see Table 2). Like in the UK, the private market leads the public real estate market in all the sectors where significance in coherence is established. Based on the transaction index, the private leads the public market respectively by $0.4,1.7$ and 3.6 quarters for the apartment, industrial and office sectors. This differs markedly from prior research because the behaviour of longer cycles rather than period-by-period return rates is now being examined.

\subsection{Across the sectors}

In Australia, the spectral density plots suggest that the private real estate is dominated by a low frequency cycle with a period of 9.5 years or longer (Figure 1), with the industrial and office sector significantly correlated at this component at $1 \%$. To confirm its existence with confidence, however, one needs at least 66.5 years of observations. In Hong Kong, the office and the retail sectors share two components: a 3.1-year and a 1.7-year cycle with the former cycle contributing more to the total variance in each case. The two sectors are also significantly correlated at these two cycles at $10 \%$ and $5 \%$ respectively, while retail leads office by 0.7 quarters at the 3.1-year cycle but lags office by 0.3 quarters at the 1.7-year cycle. We detected five components in the industrial sector, none of which are shared with any other sector

The three sectors of the private market in Singapore appear to be significantly correlated at the shared 8.5-year cyclical component with retail leading industrial by 0.6 quarters which, in turn, leads office by 0.8 quarters. The retail and office sectors are also significantly correlated at a 6.4-year 
cycle, with retail leading office by 2.1 quarters. Formally confirming the existence of these two cycles would require a longer sample. The leading position of the industrial sector over the office sector can be confirmed at a 1.3-year cycle.

In UK, we found that the three sectors of the private market are significantly correlated at a 5.25-year cycle. The retail sector leads the office sector (by 1.0 or 2.0 quarters depending on the use of transaction or appraisal data), which, in turn, leads the industrial sector (by 0.4 or 0.3 quarters depending on the use of transaction or appraisal data). The sectors also appear to be significantly correlated at a 7-year cycle, with retail leading industrial by 0.8 quarters and office leading industrial by 2.9 quarters when measured with transaction based data. Significance is only established from the appraisal data at this component between office and industrial sectors, with office leading industrial by 2.5 quarters. ${ }^{8}$ Using the appraisal series, we further found that the office sector leads both industrial and retail sectors at the minor higher frequency cycles.

In the public real estate market of the US, the apartment sector is significantly correlated with the industrial and the office sectors at the 5.5-year cycle, as is the industrial sector with the office and the retail sectors at either 5\% or $10 \%$ level, with industrial leading apartment, office and retail by $0.37,0.87$ and 0.88 quarters respectively. Meanwhile, the apartment and the retail sector are significantly correlated at $5 \%$ at their shared 1.2-year cycle, with apartment leading retail by 0.1 quarters.

In the private real estate market of the US, using appraisal indices, we establish significant coherence at the 5.5-year cycle between apartment and industrial, apartment and office, and industrial and office sectors at the $1 \%$ or $5 \%$ level and the three sectors move in near perfect tandem. Using transaction based indices, significance at this cyclical component is also established across all sectors at either $1 \%, 5 \%$ or $10 \%$, with office leading the industrial by 0.65 quarters, industrial leading apartment by 0.36 quarters, and apartment leading retail by 0.64 quarters. The only inconsistency between these results is the lead/lag relationship between industrial and office. We also found significant coherence at a 1.2-year cycle at $1 \%$ level between retail and industrial sector

\footnotetext{
${ }^{8}$ Bear in mind however that we are unable to formally confirm results related to these two cycles for private real estate until more observations become available.
} 
in the private market when transaction indices are used, with the industrial sector leading retail by 0.59 quarters.

Figure 4 Coherence and phase angle - sectors. Only significantly correlated markets/sectors are plotted. (i) coherences are measured by the left axis and phase angles in rad by the right axis. (ii)The horizontal axis indicates the period (in quarters) of each cyclical component. (iii) $(T)=$ transaction based index; $(V)=$ appraisal based index; $(E)=$ public real estate.

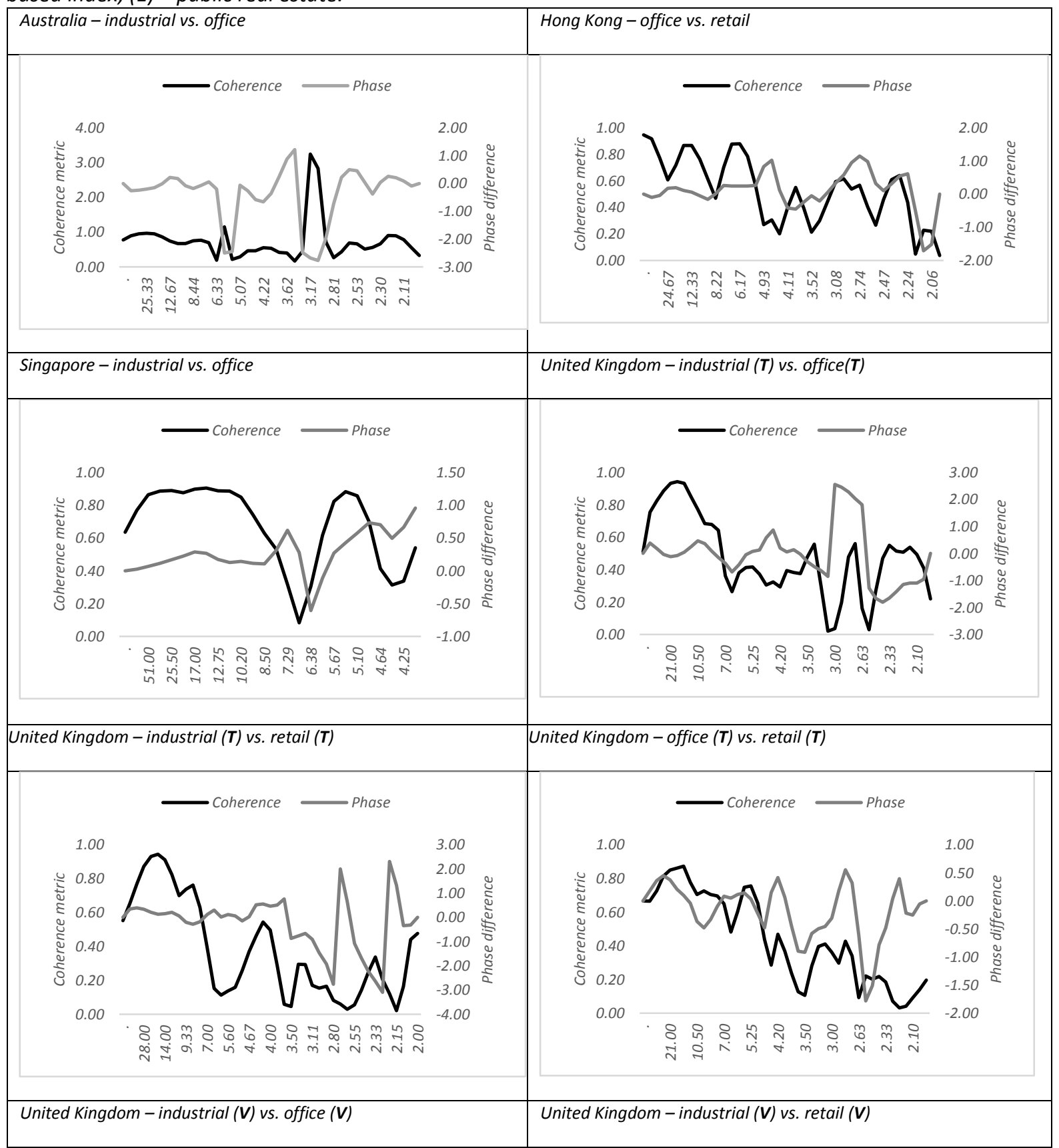




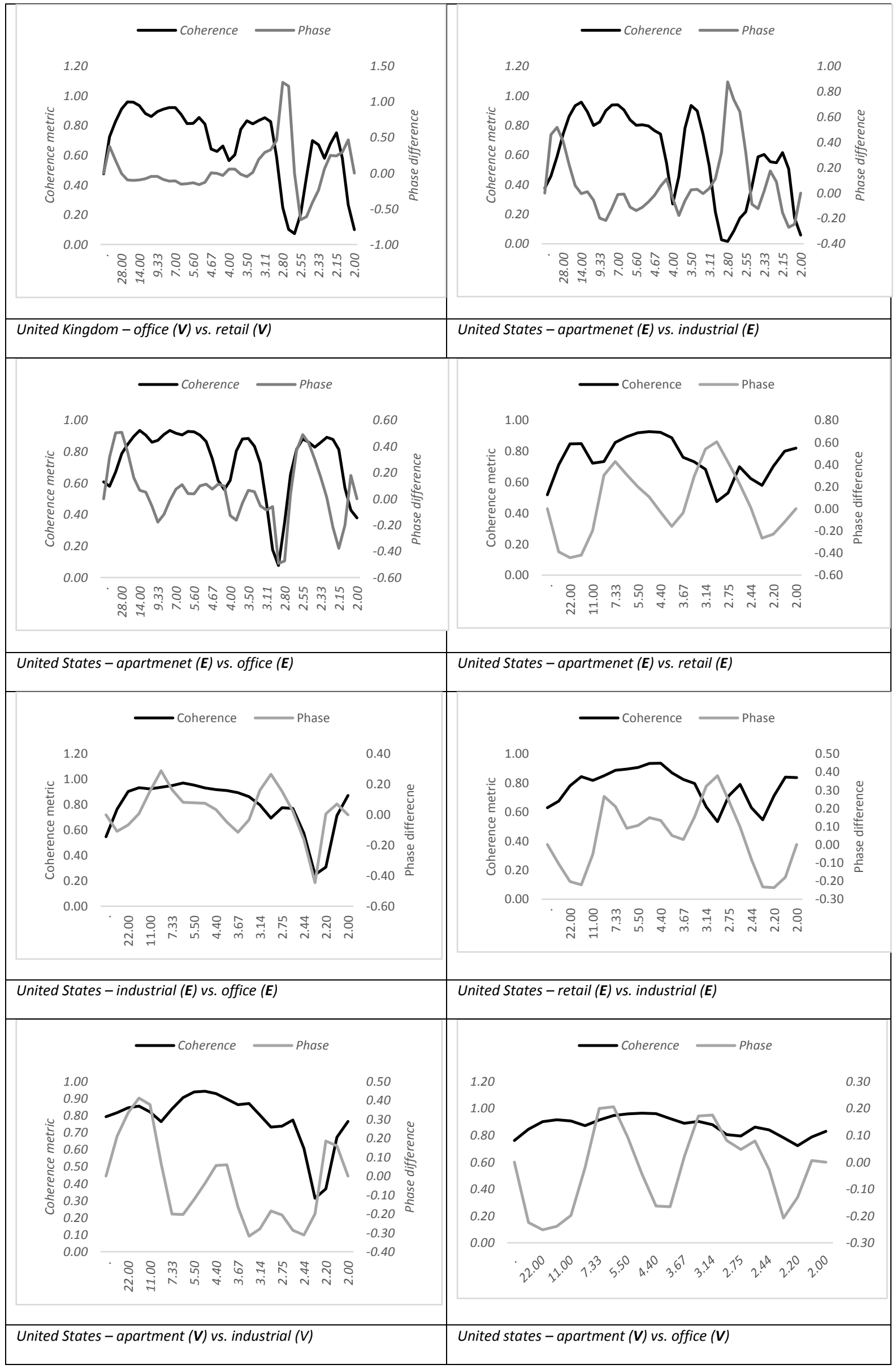

Page | 26 


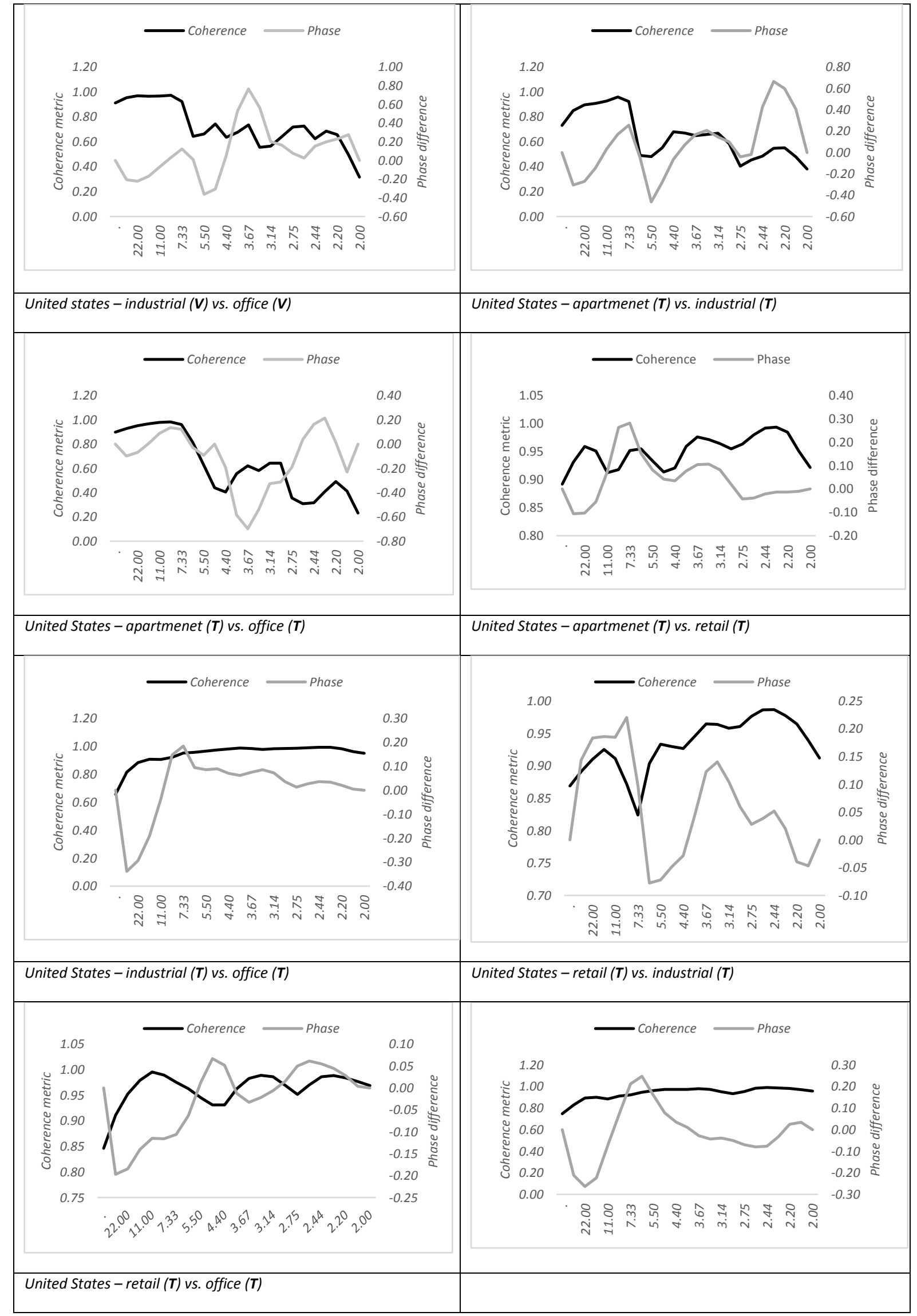

Page | 27 


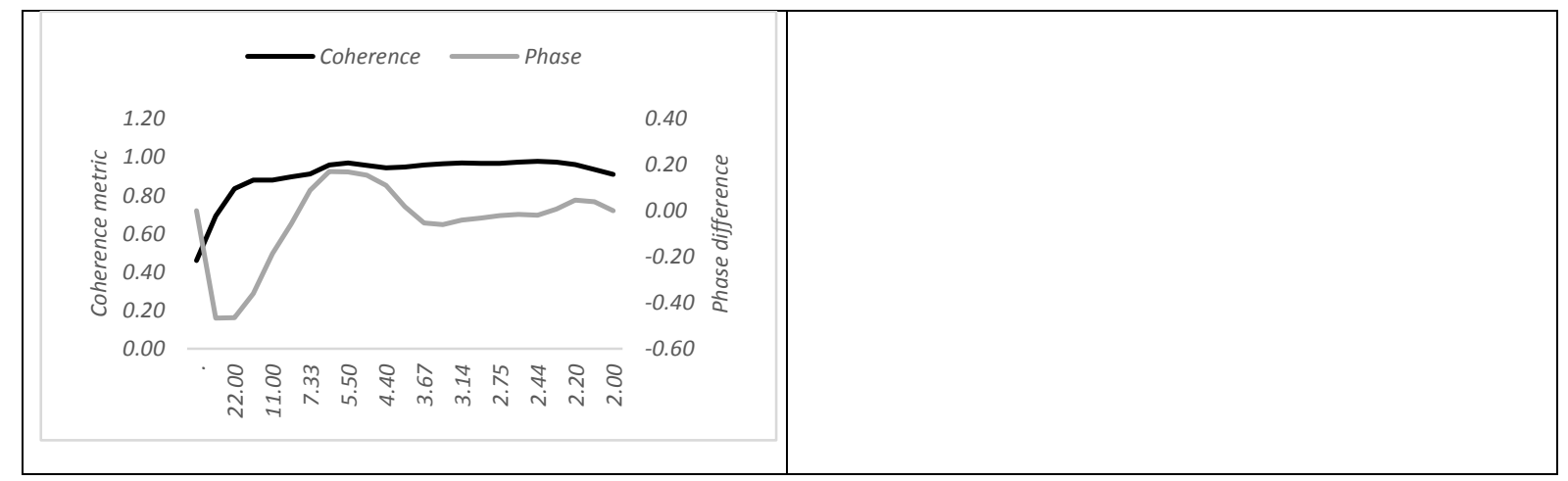

Page | 28

\subsection{Transaction vs. appraisal indices}

From discussion elsewhere in section 5, we can see that use of transaction based series for private real estate returns does modify the results in ways that cannot always be dismissed as minor. Therefore, to understand the relationship between transaction and appraisal indices further, we conducted additional cross spectral analyses for the UK and the US where both types of indices are available.

In the UK, the two indices are significantly correlated at $1 \%$ at both the 7-year and the 5.3year cycles. When measured using aggregate 'all property' data, the transaction index leads the appraisal index by 0.1 quarters at the 7 -year cycle but lags the latter by 0.1 quarters at the 5.3 -year cycle. When measured at sector level, the same pattern is exhibited only by the retail sector. The transaction index lags the appraisal index in the industrial sector, but leads the latter in the office sector. The phase difference between the two types of indices is less than 0.3 quarters in all cases. In the US, the two types of private real estate index are significantly correlated at the 5.5-year cycle at the $1 \%, 5 \%$ or $10 \%$ significance levels. Surprisingly, the transaction indices lag the appraisal indices in all sectors by values of 0.4 to 1 quarters in length (Table 2). This also contrasts with the findings of other studies that deploy time domain techniques to study these relationships.

Figure 5 Coherence and phase angle - transaction and appraisal indices for private RE. Only significantly correlated markets/sectors are plotted. (i) coherences are measured by the left axis and phase angles in rad by the right axis. (ii)The horizontal axis indicates the period (in quarters) of each cyclical component. (iii) $(T)=$ transaction based index; $(V)=$ appraisal based index; $(E)=$ public real estate.

\begin{tabular}{|l|l|}
\hline United Kingdom - (T) vs. (V) all property & United Kingdom - (T) vs. (V) industrial \\
\hline
\end{tabular}




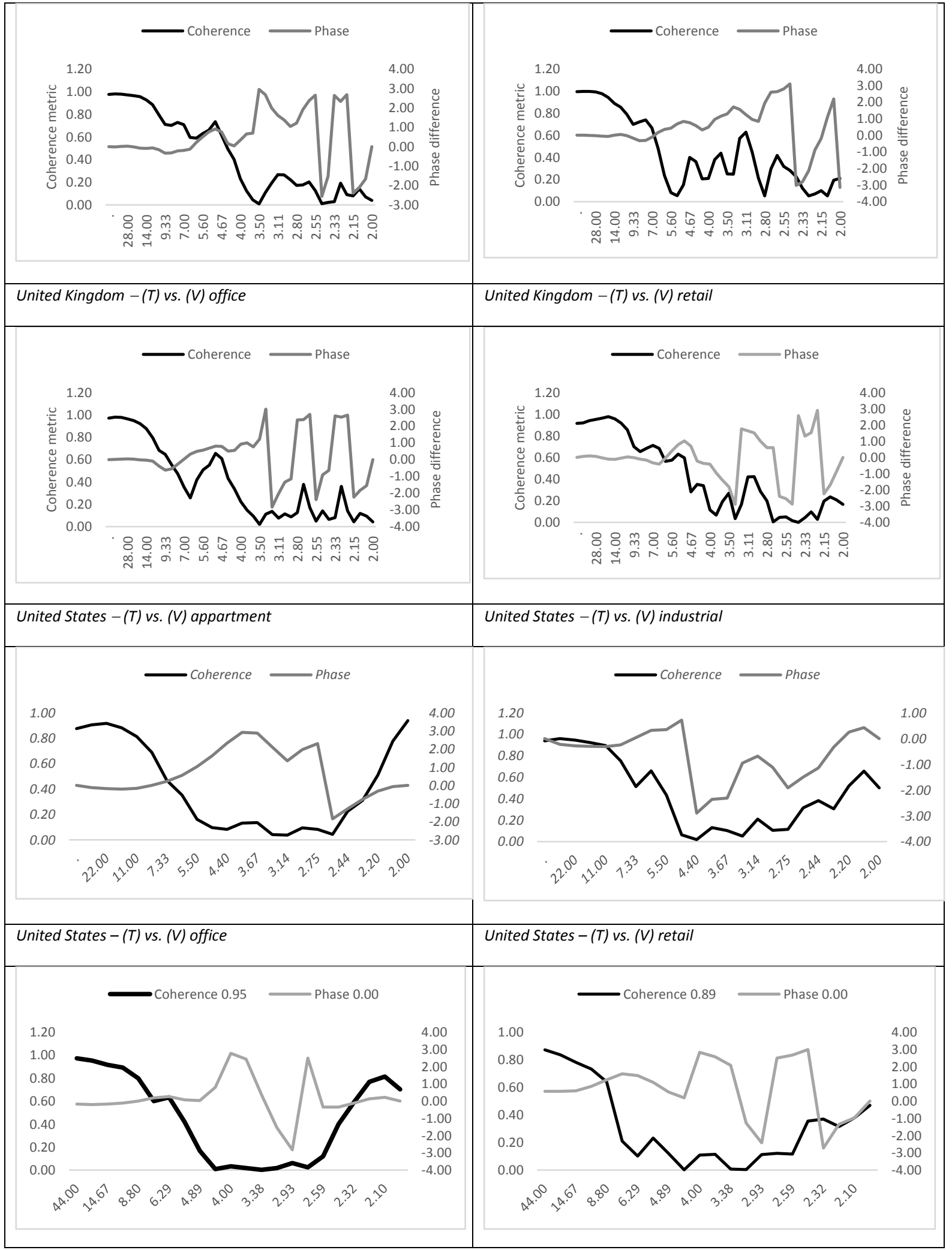

\section{Conclusion}

Previous studies have explored whether the performance of real estate shares is related more to the equity market or the private real estate market. Most of this literature has examined the 
question using time domain techniques, with many recent studies relying on cointegration as the principal method of analysis. In contrast, we utilise spectral and cross-spectral analysis together with sector-level real estate data to re-examine this question. The main advantages of these techniques are their ability to decompose a return series into different cyclical components and to measure how strongly related a pair of series are at frequency bands corresponding to these components.

Furthermore, most previous studies in this area have used appraisal based indices to measure private real estate performance. In this study, we test whether the use of transaction based series would lead to different findings for the UK and the US, where both types of indices are available. We found that, although the two types of index are strongly correlated at some low-frequency components in both countries, the relatedness of public and private real estate markets across sectors and the associated lead-lag relationships vary considerably with the type of index used.

An important concern of commercial real estate investors is whether buying real estate equities can be used as a substitute for investing directly in real estate markets. The results of our analysis feature important geographical differences. For example, we found no shared cyclical components between public and private real estate in Australia, but results for the UK and US resemble the conventional wisdom that private and public real estate are linked in the long run. However, our use of sector-level data allows us to reveal more detailed information. For instance, we found (using either transaction or appraisal data) that only the retail sector is significantly correlated with the public real estate market in the UK. In the case of US, transaction data shows associations between public real estate and the apartment, industrial and office sectors, but not retail. Different to previous studies, but perhaps in line with research suggesting feedback effects, we also found that the private market in the US leads the public market when lower frequency cycles are considered. There are also interesting relationships between different sectors of the private real estate market.

To sum up, we examined the relatedness of investment returns for private real estate, public real estate and general equities. We built on earlier literature by adopting different techniques and rarely used sector level data, by testing transaction as well as appraisal based indices for private real estate, and by covering five important commercial real estate locations in different parts of the world. Our analyses suggest that each time series scrutinized contains a major low-frequency cycle 
and one or more minor higher-frequency cycle(s). Within the same country, cycles are generally uniform in duration across different sectors of the private real estate market, but they differ across the private and public real estate markets. As for the relatedness of the three investment options and the lead-lag relationships between them, there is no universally applicable conclusion. Hence, investors must exercise caution when moving outside their conventional investment locations.

\section{References}

1. BARKHAM, R. \& GELTNER, D. 1995. Price Discovery in American and British Property Markets. Real Estate Economics, 23, 21-44.

2. BARKHAM, R. \& WARD, C. 1999. Investor Sentiment and Noise Traders: Discount to Net Asset Value in Listed Property Companies in the U.K. . Journal of Real Estate Research, 18, 291-312.

3. BARRAS, R. 2009. Building Cycles: Growth and Instability., Chichester, Wiley-Blackwell.

4. BAUM, A. \& HARTZELL, D. 2012. Global Property Investment: Strategies, Structures, Decisions. , Chichester, Wiley-Blackwell.

5. BCG 2017. Global Asset Management 2017: The Innovator's Advantage. The Boston Consulting Group.

6. BOUDRY, W., COULSON, N., KALLBERG, J. \& LIU, C. 2012. On the Hybrid Nature of REITS. Journal of Real Estate Finance and Economics 44, 230-249.

7. BROWN, G. \& LIOW, K. 2001. Cyclical relationship between commercial real estate and property stock prices. Journal of Property Research. 18, 309-320.

8. CHAN, K. F., TREEPONGKARUNA, S., BROOKS, R. \& GRAY, S. 2011. Asset market linkages: Evidence from financial, commodity and real estate assets. Journal of Banking \& Finance, 35, $1415-1426$.

9. DEVANEY, S. \& MARTINEZ DIAZ, R. 2011. Transaction based indices for the UK commercial real estate market: an exploration using IPD transaction data. Journal of Property Research, $28,269-289$. 
10. EDELSTEIN, R. \& QUAN, D. 2006. How Does Appraisal Smoothing Bias Real Estate Returns Measurement? . Journal of Real Estate Finance and Economics, 32, 41-60.

11. EICHHOLTZ, P. \& HARTZELL, D. 1996. Property Shares, Appraisals and the Stock Market: An International Perspective. Journal of Real Estate Finance and Economics, 12, 163-178.

12. FISHER, J., GELTNER, D. \& POLLAKOWSKI, H. 2007. A Quarterly Transactions-based Index of Institutional Real Estate Investment Performance and Movements in Supply and Demand. Journal of Real Estate Finance and Economics, 34, 5-33.

13. FISHER, J., GELTNER, D. \& WEBB, R. 1994. Value Indices of Commercial Real Estate: A Comparison of Index Construction Methods. Journal of Real Estate Finance and Economics, 9, 137-164.

14. GELTNER, D., MACGREGOR, B. \& SCHWANN, G. 2003. Appraisal Smoothing and Price Discovery in Real Estate Markets. Urban Studies, 40, 1047-1064.

15. GILIBERTO, S. 1990. Equity Real Estate Investment Trusts and Real Estate Returns. Journal of Real Estate Research, 5, 259-263.

16. GLASCOCK, J., LU, C. \& SO, R. 2000. Further Evidence on the Integration of REIT, Bond and Stock Returns. Journal of Real Estate Finance and Economics, 20, 177-194.

17. GRANGER, C. 1969. Investigating casual relations by econometric models and cross-spectral methods. Econometrica, 37, 424-438.

18. GRANGER, C. \& HATANAKA, M. 1964. Spectral Analysis of Economic Time Series., Princeton, Princeton University Press.

19. GRANGER, C. W. J. 1964. Spectral analysis of economic time series, Princeton, N.J.,, Princeton University Press.

20. GYOURKO, J. \& KEIM, D. 1992. What Does the Stock Market Tell Us About Real Estate Returns? . Journal of the American Real Estate and Urban Economics Association 20, 457485. 
21. HOESLI, M. \& OIKARINEN, E. 2012. Are REITs real estate? Evidence from international sector level data. Journal of International Money and Finance, 31, 1823-1850.

22. IACOBUCCI, A. (ed.) 2005. Spectral Analysis for Economic Time Series, Berlin Heidelberg: Springer.

23. LIOW, K. H. 2007. Cycles and common cycles in real estate markets. International Journal of Managerial Finance, 3, 287-305.

24. MORAWSKI, J., REHKUGLER, H. \& FUSS, R. 2008. The nature of listed real estate companies: property or equity market? . Financial Markets and Portfolio Management, , 22, 101-126.

25. MYER, F. \& WEBB, J. 1993. Return Properties of Equity REITs, Common Stocks, and Commercial Real Estate: A Comparison. Journal of Real Estate Research, 8, 87-106.

26. NNEJI, O., BROOKS, C. \& WARD, C. 2013. Commercial Real Estate and Equity Market Bubbles: Are They Contagious to REITs? Urban Studies, 50, 2496-2516.

27. OIKARINEN, E., HOESLI, M. \& SERRANO, C. 2011. The Long-Run Dynamics between Direct and Securitized Real Estate. Journal of Real Estate Research, 33, 73-102.

28. OPPENHEIMER, P. \& GRISSOM, T. 1998. Frequency Space Correlation between REITs and Capital Market Indices. Journal of Real Estate Research, 16, 291-309.

29. PREQIN 2016. Preqin investor outlook: Real estate. Preqin Research Center Premium.

30. TULUCA, S., MYER, F. \& WEBB, J. 2000. Dynamics of Private and Public Real Estate Markets. Journal of Real Estate Finance and Economics, 21, 279-296.

31. WANG, P., LIZIERI, C. \& MATYSIAK, G. 1997. Information asymmetry, long-run relationship and price discovery in property investment markets. The European Journal of Finance, 3, 261-275.

32. WHEATON, W. 1999. Real Estate "Cycles": Some Fundamentals. Real Estate Economics, 27, 209-230.

33. WILSON, P. \& OKUNEV, J. 1999. Spectral Analysis of Real Estate and Financial Assets Markets. Journal of Property Investment and Finance, 17, 61-74. 
34. YUNUS, N., HANSZ, J. \& KENNEDY, P. 2012. Dynamic Interactions Between Private and Public Real Estate Markets: Some International Evidence. Journal of Real Estate Finance and Economics, 45, 1-29.

Page | 34 